Pamiętnik Literacki 2016, 4, s. 115-147
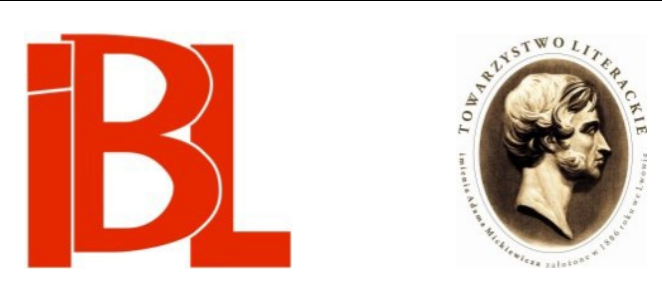

\title{
Ironia romantyczna w pisarstwie Paula
}

\section{de Mana}

Wojciech Hamerski 
WOJCIECH HAMERSKI Uniwersytet im. Adama Mickiewicza, Poznań

\title{
IRONIA ROMANTYCZNA W PISARSTWIE PAULA DE MANA*
}

\begin{abstract}
W końcu wpadła mu [tj. Henrykowi] w ręce księga napisana w obcym języku, który, jak mu się wydawało, zdradzał podobieństwo $z$ łaciną $i$ włoskim. Jak najgoręcej pragnąłby znać ten język, gdyż księga podobała mu się nadzwyczajnie, mimo że nie rozumiał z niej ani jednej zgłoski. Nie miała tytułu, lecz kartkując ją, znalazł kilka rycin. Wydało mu się, że znał je wcześniej w jakiś cudowny sposób, a kiedy dobrze się im przyjrzał, odkrył swą własną postać, dość rozpoznawalną pośród innych figur ${ }^{1}$.
\end{abstract}

\section{Ironia nie ustaje}

„Zatem ironia nie ustaje. Sam zawsze jesteś przez siebie opisany. Krytyk odnajduje samego siebie w przedsięwziętej próbie jakiejś analizy" (D 248) ${ }^{2}$ - to zgodne $\mathrm{z}$ duchem ironii, by refleksja nad pismami Paula de Mana zaczynała się in medias res, w środku myśli, w połowie zdania, w miejscu zgoła dowolnym. Nieautoryzowany wywiad, z którego pochodzi zacytowana wypowiedź, to jedno z nielicznych miejsc, gdzie de Man uczynił romantyczny koncept „transcendentalnej błazenady” przedmiotem bezpośredniej refleksji. Poza parą tekstów składających się na swoisty dwutakt ironiczny - czyli Retoryka czasowości i Pojęciem ironii - Friedrich Schle-

* Tekst powstał dzięki wsparciu z grantu NCN Ironie romantyczne (UMO-2013/11/D/HS2/04490).

1 Novalis (F. von Hardenberg), Henrykvon Ofterdingen. Przeł., oprac. E. Szy mani, W. Kunicki. Wrocław 2003, s. 94. BN II 247.

2 Skrótem D odsyłam do: „... dla mnie tak, skoro nazywam się de Man...” Z P. de Manem rozmawia R. Moynihan. „Literatura na Świecie” 1999, nr 10/11 (przeł. A. Przybysławski). Ponadto w artykule do prac P. de Mana odsyłam następującymi skrótami: A = Autobiografia jako od-twarzanie. W zb.: Dekonstrukcja w badaniach literackich. Red. R. Ny cz. Gdańsk 2000; AC = Alegorie czytania. Język figuralny u Rousseau, Nietzschego, Rilkego i Prousta. Przeł. A. Przy by sław s ki. Kraków 2004; AT = Antropomorfizm i trop w liryce. „Literatura na Świecie” 1999, nr 10/11 (przeł. T. Pi ó ro); B = Blindness and Insight. Essays in the Rhetoric of Contemporary Criticism. New York 1971; I = Ideologia estetyczna. Przeł. A. Przybysławski. Wstęp A. W armins ki. Gdańsk 2000; O = Opór wobec teorii. W zb.: Dekonstrukcja $w$ badaniach literackich; P = The Paul de Man Notebooks. Ed. M. M c Q u illa n. Edinburgh 2014; R = Retoryka czasowości. „Literatura na Świecie” 1999, nr 10/11 (przeł. A. S o s now s ki); RC = Romanticism and Contemporary Criticism. The Gauss Seminar and Other Papers. Ed. E. S. B u r t, K. N e w m a r k, A. W a r m in s ki. Baltimore 1996; RR = The Rhetoric of Romanticism. New York 2004; S = Shelley odkształcony, z figury doszczętnie odarty. „Literatura na Świecie” 2012, nr 9/10 (przeł. A. S os now s ki); SI = Struktura intencjonalna obrazu romantycznego. „Pamiętnik Literacki” 1978, z. 3 (przeł. A. Labuda). Liczby po skrótach oznaczają stronice. 
gel $^{3}$ nie pojawia się $\mathrm{w}$ twórczości de Mana w pierwszoplanowej roli, można więc powiedzieć, że ironia nie wydaje się, przynajmniej na poziomie tematu, permanentna. Jest to konstatacja o tyle myląca, że wiele struktur myślowych, wyprowadzonych $\mathrm{z}$ analizy koncepcji istotnej dla wczesnego romantyzmu niemieckiego, działa potajemnie, gdy de Man zajmuje się czymś zupełnie innym, np. utworami pisarzy nie kojarzonych $\mathrm{z}$ ironią (takich jak W. Wordsworth czy J. J. Rousseau), pojęciami alegorii, referencji i materialności, a nawet gdy omawia własną metodę badawcza, na co zwrócił uwagę chociażby Adam Lipszyc: „istnieje ścisły związek pomiędzy pojęciem ironii i dekonstrukcji [...]" ${ }^{4}$. Ironia żyje w domyśle, wzmiankach i aluzjach - stanowiąc „coś w rodzaju negatywnej siły języka” ${ }^{5}$, jest dla de Mana zbyt cenna, by dało się o niej łatwo zapomnieć.

Od przedmiotowego traktowania ironii w źródłowym kontekście romantycznym, przez jawne lub ukryte zastosowanie tego ujęcia w tekstach innych epok i niekoniecznie literackich, prowadzi przejście ku najbardziej uwewnętrznionemu sposobowi jej funkcjonowania w książkach autora Alegorii czytania. Nikt nie wyraził tego zwięźlej niż jego przyjaciel, Jacques Derrida: „Paul sam był ironią” ${ }^{6}$ Ta tożsamość ironiczna przejawia się na poziomie stylu, ale nie daje się do niego zredukować. Natomiast według Marii Bożenny Fedewicz, chociaż „De Man ironizuje, często posługuje się paradoksem”, to „zawsze jest w tym głębokie serio” ${ }^{7}$. Przy takim założeniu da się w zasadzie syntezować myśl badacza $z$ pominięciem problemu ironii. Tak dzieje się w książce Christophera Norrisa, w której pojawia się on tylko migawkowo i w polemicznym kontekście historycznym (jako jeden $\mathrm{z}$ uprzywilejowanych przez Nową Krytykę trybów retorycznych, pozwalających - rzekomo według de Mana - odróżnić poezję od zwykłego języka ${ }^{8}$ ). Jest wszakże charakterystyczne, że bodaj jedyna wykraczająca poza ten kontekst wzmianka o ironii nie wiąże się $z$ tematem prac literaturoznawcy, ale $\mathrm{z}$ ich formą:

Styl Paula de Mana cechuje naprzemienny rytm twierdzeń o stanowczym, pewnym siebie, a nawet apodyktycznym charakterze i momentów ironicznej refleksji, w których owe twierdzenia są podawane w watpliwość $c^{9}$.

3 De Man rekonstruuje „pojęcie ironii” głównie na podstawie wczesnych prac młodszego z braci Schleglów, jedynie wzmiankując technikę deziluzji teatralnej L. Tiecka, teorię humoru u Jean Paula i K. W. F. Solgera, nieco dłuższy passus poświęca Księżniczce Brambilli E. T. A. Hoffm a n n a. Warto dodać, że belgijski literaturoznawca rzadko używa określenia „ironia romantyczna” (pojawia się ono bodaj raz - w Retoryce czasowości), w czym jest akurat solidarny ze Schleglem. A. Li p s zy c, Międzyludzie. Koncepcja podmiotowości w pismach Harolda Blooma z nieustającym odniesieniem do podmiotoburstwa. Kraków 2004, s. 139.

5 M. P. Markowski, Dekonstrukcja. W: A. Burzyńska, M. P. Markowski, Teorie literatury XX wieku. Podręcznik. Kraków 2006, s. 377.

6 J. D e rrid a, (In Memorium) Paul de Man. W zb.: Deconstruction. A Reader. Ed. M. M c Q u illa n. New York 2001, s. 468.

7 M. B. F e d e w i c z, Paul de Man o literaturze romantycznej. „Pamiętnik Literacki” 1988, z. 1, s. 140.

8 Ch. Norris, Paul de Man. Deconstruction and the Critique of Aesthetic Ideology. New York 1988. s. 39, 112. Stosunek de Mana do Nowej Krytyki był złożony - z jednej strony wyrósł on właśnie ze szkoły close reading, wrażliwej na tropy i odpornej na ideologiczne przedsądy, z drugiej nie zgadzał się z uprzywilejowaniem poezji, uważał, że „każdy język jest do pewnego stopnia literacki” (ibidem, s. XI).

$9 \quad$ Ibidem, s. 26. 
Oscylacja między asercją a negacją zagraża stabilności poznawczej wywodu, który zamienia się w narracyjne exemplum (czyli alegorię, używając terminu de Mana) podstawowej tezy dekonstrukcjonisty, mówiącej o nieuniknionym osunięciu się każdego wywodu $\mathrm{z}$ epistemologii w retorykę. W momencie, w którym „znika ostrość sądu "tak-nie", a pojawia się gra pomiędzy "serio" - "nie serio" 10, argumentacja autora Ideologii estetycznej zaczyna wychylać się w stronę ironii, problem zaś stylu, a właściwie retoryki, nie daje się już łatwo oddzielić od kwestii poznawczego statusu tekstu. Oczywiście, to kłopotliwe położenie dotyczy również pism de Mana - przeoczenie tego faktu lub jego celowe pominięcie było aktem założycielskim niektórych polemik $\mathrm{z}$ tezami badacza, traktowanymi niekiedy, jak postaram się przekonać, nieco zbyt serio.

Konsekwencję rozumienia literackości jako retoryczności języka stanowi splątanie filozofii z literaturą, literatury z krytyka - de Man sam waha się, czy nazwać to wyrokiem czy raczej przywilejem ${ }^{11}$. Rodolphe Gasché we wprowadzeniu do książki zrodzonej właśnie $z$ fascynacji osobliwościami pisarstwa dekonstrukcjonisty kładzie nacisk na jego idiosynkratyczny synkretyzm, ocierający się o niezrozumiałość $^{12}$. Odsyła on wprost do ironicznej idei mieszaniny (Mischung), której zadaniem było m.in. „zbliżyć poezję do filozofii i retoryki” ${ }^{13}$. Filozof, odkrywając w sobie „retora w przebraniu” (I 68), oddziela się od swoich „apodyktycznych twierdzeń" i przygląda się im z dystansu, który może kojarzyć się z dialektyką ironii, pozwalająca podmiotowi „unosić się na skrzydłach refleksji [...], potęgując tę refleksję i powielając w nieskończonym szeregu luster" 14 .

Skoro „sam zawsze jesteś przez siebie opisany”, to pisząc o ironii, „sam jesteś ironią". De Manowska autodiagnoza oraz jej powtórzenie u Derridy stanowią echo cytowanego już wcześniej słynnego fragmentu $z$ „Athenaeum”: „niejeden artysta, chcąc jedynie napisać powieść, przedstawił niechcący samego siebie" ${ }^{15}$. Zreinterpretowana i zasymilowana ironia romantyczna staje się zasadą funkcjonowania dzieł de Mana (realizowaną często już na poziomie estetycznym), które wielokrotnie inscenizuja własne odczytanie, będące zawsze procesem bez syntezy w postaci rozumiejącej i zrozumiałej kody. Ironia wsiąka w dyskurs, stając się jego strategią (lub wręcz sposobem istnienia), z której wtórnie wyłania się podmiot - ,jesteśmy bardziej jej [tj. strategii] wytworem aniżeli użytkownikiem [...]” (S 270) - przy czym

W. Sztu r c, Ironia romantyczna. Pojęcie, granice i poetyka. Warszawa 1992, s. 6.

O tym, na co „skazuje” lub do czego „uprzywilejowuje” figuralność języka, pisał de Man niejednokrotnie, np. w konkluzji Epistemologii metafory: „Wszelka filozofia w takim stopniu, w jakim zależy od figuracji, skazana jest na literackość, a jako depozytariusz tego właśnie problemu wszelka literatura jest do pewnego stopnia filozoficzna" (I 69). Z kolei pointa eseju Semiologia a retoryka brzmi tak: „Literatura w równym stopniu co krytyka - albowiem różnica między nimi jest złudna - jest skazana (choć może to jej przywilej) na to, że zawsze będzie rygorystycznym, a w konsekwencji najbardziej niegodnym zaufania językiem, dzięki któremu człowiek nazywa i przekształca sam siebie" (AC 31-32).

R. G a s c hé, The Wild Card of Reading. On Paul de Man. Cambrige, Mass., 1998, s. 4.

F. Schleg el, Fragmenty. Przeł. C. B artl. Oprac., wstęp, komentarz M. P. Markowski. Kraków 2009, s. 60.

Ibidem, s. 61.

Ibidem. 
perspektywa biograficzna zdolna jest, oczywiście, ów opis odwrócić, pokazując ironizację dyskursu jako uzewnętrznienie doświadczenia samego de Mana ${ }^{16}$.

W zacytowanym na poczatku wywiadzie, nagranym w 1980 roku, de Man odnosi się pośrednio również do problemu biografii. Zagadnięty przez Roberta Moynihana o ironię, odpowiada przykładem, który pochodzi $\mathrm{z}$ opublikowanego pod koniec 1979 roku artykułu Autobiografiajako od-twarzanie. Powołuje się w nim na cykl trzech Esejów o epitafiach Williama Wordswortha, poety, o którym w Retoryce czasowości mówi się, że „nie robi użytku z ironii” (R 216). W esejach, jak pisał de Man, poeta „Z cała moca wymowy broni jasnego języka spoczynku, spokoju i łagodności”, potępiając „antytetyczny język satyry oraz inwektywy” (A 121), reprezentowany przez kilku uznanych twórców epitafiów (a epitafium to figuralny korelat autobiografii w formie inskrypcji na pomniku), wśród których najważniejszy jest Alexander Pope. Trzeci z esejów rozpoczyna się jednak od niespodziewanego ataku na Pope’a, więc nastrój spokojnej zadumy pryska. Jest to, jak pisze de Man, „główna niekonsekwencja tekstu” (A 121): „nie ma bowiem najmniejszego powodu, dla którego z Pope'em nie można by się było obchodzić z tą samą dialektyczną wielkodusznością należną śmierci [...]" (A 122). Krytyka Pope’a skrywa niezgodę na odległy od natury język figur, zasilający jednak, jak wykazuje badacz, również preferowany przez Wordswortha model epitafium - kamienie przemawiają u niego głosami zmarłych, a słońce zamienia się $\mathrm{w}$ oko, które czyta inskrypcje nagrobne.

W późniejszym wywiadzie de Man, zbaczając $z$ kursu argumentacji obranego w artykule Autobiografia jako od-twarzanie ${ }^{17}$, uwypukla myśl o „niekonsekwencji tekstu" i doprowadza ją do nowej konkluzji:

kiedy [Wordsworth] zaczyna pisać o Pope’ie, to robi to właśnie w taki sposób, jaki ganił w pisarstwie Pope'a. W tym momencie Wordsworth w pewnym sensie traci kontrolę. [...] Tego typu moment nazwalbym momentem ironicznym. [D 247]

W obu komentarzach do Esejów o epitafiach badacz akcentuje niespójność poety romantycznego, po czym jednak droga rozumowania rozwidla się, doprowadzając do pozornie rozbieżnych wniosków - w artykule docieramy do prozopopei jako „figury rozumienia”, polegającej na „przydawaniu maski”, w wywiadzie zaś do

16 Tak postępuje E. B a r i s h (The Double Life of Paul de Man. New York 2014, s. 427), autorka biografii dekonstrukcjonisty, która zastanawia się, „w jakim kotle doświadczenia zrodziła się dekonstrukcja”, i stawia hipotezę, że nacisk, jaki metoda ta kładła na podwójność i ironię, „zdawał się odbijać przepełniona cierpieniami narracje pierwszej połowy XX wieku”. Życie de Mana stało się fragmentem tej narracji za sprawą niechlubnych wojennych publikacji w belgijskim piśmie „Le Soir", ale wpływ na niego miały również traumatyczne doświadczenia (odkrycie w młodości przez chłopca zwłok matki, która popełniła samobójstwo przez powieszenie, silne oddziaływanie wuja, Henriego de Mana, intensywnie kolaborującego z Niemcami). Barish odnotowuje także wrodzony oportunizm chłopca z dobrej rodziny, który sprawiał, że Paul de Man nie cofał się przed krzywdzeniem bliskich dla własnych korzyści (podobno jeszcze w Belgii, fałszując dokumenty i defraudując kapitał, doprowadził do ruiny wydawnictwo „Hermes”, utrzymywał dzieci z obu małżeństw w nieświadomości istnienia rodzeństwa). W Ameryce podjął „świadomy wysiłek”, by stworzyć siebie na nowo - hulaszcze życie zastapił ascetyczną egzystencją wycofanego i tajemniczego profesora.

17 Argumentacja ta zmierza do wykazania, że autobiografia to nie sposób pisania (gatunek) stanowiący „wiarygodne świadectwo samopoznania” (A 111), ale konwencja czytania, „figura rozumienia” (A 110), której głównym tropem jest nadawanie zmarłemu głosu i twarzy, czyli prozopopeja, apostrofa do zmarłego, zakładająca możliwość jego odpowiedzi. 
ironii, która rozumienie uniemożliwia (jej synonim stanowi u de Mana, tak jak u Schlegla, parabaza odsyłająca do momentu deziluzji w sztuce, czyli do zdejmowania maski). Można by się zastanawiać, czy nie jest to „główna niekonsekwencja” argumentacji de Mana, który po opisaniu niespójności Wordswortha przecież ostrzegał, iż „utrata kontroli” zagraża wszystkim tekstom:

czytelnik [...] myśli, że zyskuje trochę kontroli nad Wordsworthem. Właśnie w tym momencie czytelnik powinien się strzec, ponieważ powtarza się tu ten sam proces, co u Wordswortha, któremu się wydawało, że zyskuje kontrolę nad Pope'em. [D 248]

Skoro jednak nawet najbardziej rygorystyczny język, jak pisał de Man w artykule Semiologia a retoryka, nie jest "godny zaufania”, to może warto zawierzyć brakowi rygoru - oba ujęcia wydają się komplementarne, a ich zestawienie pozwala na prowizoryczne uogólnienie. Zyskiwanie twarzy w autobiografii to przyjmowanie figury (jako kształtu oraz metafory: oko słońca, głos kamienia), wytwarzające fikcje głosu zza grobu. Trudno wszakże traktować ów głos jako „wiarygodne świadectwo samopoznania" (A 111), skoro sam poeta odrzuca figurę, którą jednocześnie akceptuje. „Utrata kontroli” nad prozopopeja prowadzi z kolei do demaskacji figury (defiguracji), w wyniku czego „słoneczny język poznania” (A 123) generujący efekt prawdy w autobiografii ujawnia swój „referencjalnie aberracyjny” (RC 174) retoryczny tryb zapośredniczający poznanie: „Autobiografia ukrywa [...] od-twarzanie [z pomoca tropu prawdy - W. H.], które sama powoduje [demaskując prawdę o pośrednictwie tropu - W. H.]" (A 124).

W zakończeniu trzeciego eseju o epitafiach Wordsworth przytacza fragment swojego autobiograficznego poematu Wycieczka. Bohater liryczny, pozbawiony słuchu, zostaje w nim przeciwstawiony przyrodzie, symetrycznie pozbawionej głosu, co według de Mana może sugerować, że poeta, któremu przez chwilę zdawało się, iż słyszy głos dobywający się z kamienia, uzmysłowił sobie swoją głuchotę. Rozmowa z Moynihanem rzuca nowe światło na konkluzję artykułu - późniejszy komentarz legitymuje lekturę wcześniejszego tekstu w ironicznym układzie odniesienia. Możemy więc, po pierwsze, przeczytać Autobiografie jako od-twarzanie jako rzecz o Wordsworthie: opowieść o „niekonsekwencji”, „utracie kontroli” i uświadomieniu sobie własnej głuchoty byłaby ilustracją ironii opisanej przez de Mana jako dialektyczna gra dystansów w podmiocie, tocząca się w rytmie iluzji i deziluzji, autokreacji i autodestrukcji (tak ironia została przedstawiona w Retoryce czasowości). Artykuł Autobiografia jako od-twarzanie zawiera jednak, po drugie, również teorię autobiografii, a w zasadzie wszystkich tekstów (de Man uważa przecież, że „każda książka z czytelną stroną tytułową jest do pewnego stopnia autobiograficzna" (A 110〉), stanowiącą zarazem teorię rozumienia, czyli czytania. Autobiografia, skrywając efekt, który ją wytwarza, byłaby więc modelem każdego tekstu współtworzonego przez figurę i jej dekonstrukcje, narrację i jej Innego, pozbawionego twarzy - ironię. Takie odczytanie odpowiadałoby drugiemu ujęciu koncepcji Schlegla, zaprezentowanemu przez de Mana w wykładzie Pojęcie ironii.

\section{Ironiczna palinodia}

W Retoryce czasowości ironia zjawia się późno. Artykuł de Mana celebruje własną czasowość, powoli odsłaniając horyzont poznawczy - naprzód dokonuje przesunięć 
w waloryzacji symbolu i alegorii, dopiero na tym tle zarysowuje wzajemną relację drugiej pary pojęć, którą tworzą alegoria i ironia. Pierwszą część tekstu cechują przejrzystość i potoczystość (rzadkie u de Mana), których polskiemu czytelnikowi nie zakłóca nawet mniejsza żywotność omawianej opozycji na rodzimym gruncie (pomogła ona - jak twierdzi Michał Głowiński - „uniknąc zdyskwalifikowania alegorii jako zdezaktualizowanego sposobu uprawiania i rozumienia literatury [...]" ${ }^{18}$ ). De Man, posługując się terminami Samuela T. Coleridge’a, podważa wyższość organicznego symbolu nad mechaniczną, ,oschle racjonalną i dogmatyczną” (R 193) alegorią. Konkluzje badacza sa dobrze znane - alegoria „udaremnia iluzoryczne utożsamienie ja z nie-ja” w symbolu, a rozwianie tej „nieustępliwej automistyfikacji” wymaga otwarcia się na „negatywną samowiedzę" o temporalnej nieprzyległości przeżycia i przedstawienia, wyrzeczenia się „nostalgii i pragnienia jednoczesności” (R 215).

Pojęcie alegorii, umożliwiające dyskursywny opis „niewyobrażalnego dotyku czasu"19, stanowi pasaż, którym myśl autora przechodzi od symbolu do ironii. De Man wyprowadza swoje rozumienie ironii ze sformułowanej przez Charles'a Baudelaire’a idei „absolutnej komiczności”, ,jednej z licznych pestek zawartych w symbolicznym jabłku" ${ }^{20}$. Przykłady teatralne ilustrujace definicje poety - takie jak angielska arlekinada czy fabuła Księżniczki Brambilli Hoffmanna - umożliwiają rozumienie ,istoty śmiechu” jako pokrewnej scenicznej ironii, jednak decydujace znaczenie dla wywodu de Mana ma opis filozoficznej zdolności do śmiania się z własnego upadku, „siły szybkiego rozdwajania sie”, pozwalającej „uczestniczyć jako bezinteresowny widz w spektaklach własnego ja" ${ }^{21}$. Baudelaire dostarcza więc anegdotyczna matrycę dla koncepcji ironii jako dialektycznej struktury czasowej w obrębie ,ja”. Wiedza o wystającym korzeniu, zamaskowanym stopniu czy wyrwie w chodniku przychodzi zawsze za późno: przyszłości „nigdy nie przestaje nękać groźba ponownego upadku w nieautentyczność" (R 233). Dwa długie cytaty ze Schlegla, fragment $116 \mathrm{z}$ „Athenaeum” oraz passus z późniejszego eseju $O$ niezrozumiałości, mają za zadanie ukazać chroniczność wspomnianej groźby - dynamika refleksji jest nieustająca, a parabaza permanentna, o czym niemiecki romantyk mówi „z rozradowaniem”.

Alegoria i ironia, twierdzi de Man, są więc dostarczycielkami tej samej wiedzy negatywnej, chociaż mają swoje specjalizacje. Czasowe rozdwojenie alegorii (rozpiętej między znakiem przedstawiającym i przedstawianym: „do istoty poprzedzającego znaku należy czysta uprzedniość” 〈R 214〉) uderza w iluzje jednoczesności w symbolu, natomiast temporalna struktura ironii (,akt ironii wykazuje istnienie

M. Głowiński, Symbol i alegoria. Hasło w: Stownik literatury polskiej XIX wieku. Red. J. Bachórz, A. Kowalczykowa. Wyd. 3, bez zmian. Wrocław 2002, s. 914.

19 To sformułowanie - jedno z ulubionych przez de Mana w poezji Wordswortha - pochodzące z wiersza Mutability było pomyślane jako tytuł planowanej pod koniec życia książki o romantyzmie, w której - poza kilkoma pracami znanymi z wydanej pośmiertnie The Rhetoric of Romanticism-miały znaleźć się już istniejące, przerobione i jeszcze nie napisane teksty o romantyzmie, m.in. o J. Keatsie, F. Hölderlinie, Madame de Staël, J. J. Rousseau. Zob. spis treści planowanej książki - P 285.

20 Ch. B a u d el a ir e, O istocie śmiechu i ogólniej o komiczności $w$ sztukach plastycznych. „Literatura na Świecie” 1999, nr 10/11, s. 170 (przeł. M. Bień c zy k).

$21 \quad$ Ibidem, s. 177. 
pewnej czasowości, która na pewno nie jest organiczna, jako że odnosi się do swojego źródła tylko poprzez dystans i różnicę [...]”, R 233) występuje przeciw iluzji przedmiotowej (mimetycznej) narracji, blokującej autorefleksyjność „ja” (czyli np. samoświadomość podmiotu wypowiadającego się w powieści czy poemacie ironicznym). Chociaż powiązania ironii $\mathrm{z}$ alegorią nie można $\mathrm{w}$ żadnym razie uznać za odkrycie (np. M. F. Kwintylian pisał o ironii jako o odmianie alegorii ${ }^{22}$ ), to ich sojusz mający na celu „demistyfikację organicznego świata” (RC 407) jest niecodzienny. Wywód dopełniony jest przeciwstawieniem: ciagłość alegorii - natychmiastowość ironii: „Ironia to struktura synchroniczna, natomiast alegoria wygląda na formę generującą następstwa [...]” (R 238). Mądrość alegorii sączymy niespiesznie, ujawnia się w niej „skłonność języka do narracji, owo rozpościeranie się wzdłuż osi wyimaginowanego czasu, aby nadać trwanie temu, co faktycznie jednoczesne w obrębie podmiotu” (R 238), „staccato ironii” zaś (R 241) dostarcza olśnień błyskawicowych. Derrida w wykładzie, będącym zarazem wspomnieniem o de Manie, włącza obie „widmowe figury”, czyli „alegoryczną Mnemosyne i ironiczną Lete” ${ }^{23}$, w dekonstrukcyjną retorykę pamięci, zarządzająca - jak przenikliwie zauważa stylem myślenia autora. To, co narracyjna alegoria próbuje utrwalić, zostaje natychmiast zapomniane przez raptowną ironię, „tak jakby moment ironiczny był zapisany, zapieczętowany w ciele alegorycznego pisma” 24 .

Najistotniejszy komentarz de Mana do teorii Schlegla, czyli Pojęcie ironii, wykład wygłoszony w 1977 roku na uniwersytecie w Ohio, przyjmuje kształt palinodii, odwołującej przedstawioną tu koncepcję ironii. Wśród trzech głównych metod neutralizowania ironii, czyli unikania jej faktycznych konsekwencji, badacz wymienia „zredukowanie jej do dialektyki Ja jako struktury zwrotnej”, po czym dodaje:

W taki sposób sam się nią zajmowałem w moich wcześniejszych tekstach - dlatego też to, co dziś mówię, ma charakter s a mokry ty ki, albowiem taką możliwość chcę zakwestionować. [I 261]

Do tej samokrytyki trzeba odnieść się z podejrzliwością. Pojęcie ironii, inaczej niż metodyczny wywód w Retoryce czasowości, zachowuje wszystkie uroki oraz pułapki tekstu mówionego (jest to zapis nagrania magnetofonowego) rozwijającego się dzięki trzem zestawom notatek, ale nie pozbawionego elementu improwizacji. Zarówno entuzjastycznie, jak i sceptycznie nastawieni słuchacze de Mana wspominają, że jego wykłady spowijała „aura tajemniczości” ${ }^{25}$. Jej roztaczaniu sprzyja-

M. F. Kwintylian, Kształcenie mówcy. Księgi VIII 6 - XII. Wstęp, przekł., przypisy S. Śn i ė̇ew s ki. Kraków 2012, s. 47-48: „Do tego rodzaju alegorii, przez którą wskazuje się to, co przeciwne, należy eì

J. D e r rid a, Mémoires: for Paul de Man. Transl. C. Lind s ay, J. Culle r, E. Ca d a va. New York 1986, s. 84.

Ibidem.

Tak ujął to A. Warminski (Material Inscriptions. Rhetorical Reading in Practice and Theory. Edinburgh 2013, s. 217-218), który zapisał się na początku lat siedemdziesiątych XX wieku na kurs de Mana za radą mało znanego wówczas profesora E. Saida. Warminski był uczniem, a później współpracownikiem i jednym z zarządców pośmiertnej spuścizny de Mana. K. Newmark, również jego uczeń, wspomina z kolei (poświęcone G. W. F. Heglowi) seminarium z 1980 roku, na którym prowadzący znienacka zamilkł, po chwili zaś zrobił wtręt dotyczący Bojaźni i drżenia S. Ki e rkega arda, zastanawiając się, jak niespodziewany zwrot akcji w historii Abrahama wyglądał 
ła forma hybrydyczna - synkretyzm dyskursywny, mieszanie powagi z ironia, skłonność do paradoksów, aforyzmów, dygresji, elementy improwizacji, autotematyczne wtręty i enigmatyczne konkluzje nadają wykładowi kapryśny kształt, kojarzący się z arabeską, uważana przez Schlegla „za bardzo wyraźną i istotną formę albo przejaw poezji” 26 .

Ponownie nasuwa się wniosek, że de Mana nie zawsze można czytać dosłownie, próba mimetycznej rekonstrukcji tez teoretycznych, nie uwzględniająca ironicznego nastroju, którymi są nasycone, może okazać się dziełem „harmonijnego spłyciarza”, nie wiedzacego, jak rozumieć „ciagłą autoparodię” ${ }^{27}$, widoczną w praktyce pisarskiej belgijskiego literaturoznawcy. Dotyczy to również przywołanej autorefutacji - po pierwsze, późniejsze ujęcie tematu nie kwestionuje wcześniejszego en bloc (Lipszyc zwraca uwagę na pomost łączący teksty, jakim jest „relacja pomiędzy czasem a ironią" ${ }^{28}$ ), po drugie, wchodzi $z$ nim w interakcję ironiczną. Nie można nawet wykluczyć, że samokrytyka to chwyt reklamowy wykładowcy, który w trybie ironicznym, zbliżonym do Palinodii Ignacego Krasickiego, zachęca swoich studentów: „Przychodźcie, com niebacznie powiedział, odwołam” 29.

Zanegowane stanowisko badacz streszcza następująco: „Ironia jest wyraźnie takim samym dystansem w Ja, podwojeniem Ja, zwierciadlanymi strukturami w Ja, w których Ja patrzy na siebie z pewnego dystansu" (I 261). W momencie, w którym słuchacze (i czytelnicy) orientują się, że wytworzenie „zwierciadlanej struktury w Ja" jest tyleż tematem samokrytyki, co sposobem jej działania, relacja między Retoryka czasowości a Pojęciem ironii zacieśnia się. De Man sam zamienia się w filozofa, który z dystansu przygląda się własnemu upadkowi, odwołuje poprzednie poglądy, inscenizując je ex cathedra. Powtórzenie jakiejś narracji (np. opisującej czasowe następstwo upadania i wstawania) na innym poziomie (np. jako dramatyzacja tezy) w słowniku badacza nosi nazwę alegorii. Palinodia w Pojęciu ironii, rozumiana jako „alegoria ironii” z Retoryki czasowości, zawiązuje ciche porozumienie $\mathrm{z}$ zakończeniem wcześniejszego tekstu, w którym została poddana nobilitacji, jako rzadka realizacja tej unikatowej formy, Pustelnia parmeńska Stendhala, „powieść nad powieściami”.

A zatem położenie de Mana, uczestniczącego jako widz w „spektaklach własnego ja”, nie jest bezpieczne, grozi kolejną wywrotką (popadnięciem w nieskrom-

z perspektywy barana, który został złożony w ofierze zamiast Izaaka. Takim samym zwrotem akcji - a może lepiej powiedzieć, anakolutem czy parabazą - był ironiczny wtręt de Mana będący „okazją” do powstania książki K. N e w m a r k a o ironii (Irony on Occasion. From Schlegel and Kierkegaard to Derrida and de Man. New York 2012, s. 2). Nawet nieprzychylna dekonstrukcjoniście B a r is h (op. cit., s. 395) kilkakrotnie zastanawia się w jego biografii nad fenomenem charyzmy de Mana, który był nauczycielem „pozornie surowym i nieprzystępnym”, ale wzbudzał aplauz. Autorka chętnie przytacza też opinie słuchaczy, którzy mieli go za hochsztaplera, wykorzystującego swą czarującą powierzchowność. B a ri s h (op. cit., s. 443) zadaje sobie pytanie: „Co sprawia, że ludzie podążają za czymś, czego nie rozumieją?"

26 F. S c hl e g e l, Rozmowa o poezji. W zb.: Pisma teoretyczne niemieckich romantyków. Wybór, oprac.

T. N a mowi c z. Wrocław 2000, s. 167 (przeł. J. E ki er). BN II 246.

27 Schlegel, Fragmenty, s. 27.

28 Lipszyc, op. cit., s. 149.

29 I. Kra sicki, Odwołanie. W: Dzieła Krasickiego. Dziesięć tomów w jednym. Z portretem autora. Paryż-Genewa 1830, s. 127. 
ność), która nie musi być ostatnia, jako że dialektyka ironii to „nieskończony proces bez syntezy” (R 231), „vertige, oszołomienie aż po punkt graniczny szaleństwa” (R 225). Jak widać, ze stanowiska ironii jako dialektyki podmiotu będącej przedmiotem performance’u de Mana, tezy z Pojęcia ironii mogá zostać zanegowane ironicznie, jeszcze zanim je wypowiedziano, pomimo iż samo to stanowisko również zostało podważone. Wykładowca robi zatem coś innego, niż twierdzi, że robi, co jest ironiczne, a przy okazji w pośredni sposób komunikuje aporię języka performatywnego i konstatywnego, która zawiesza możliwość pojęcia Pojęcia ironii: „Nie zrozumieją Państwo nigdy - możemy więc na tym skończyć i pójść do domu” (I 252).

$\mathrm{W}$ artykule $\mathrm{z}$ lat sześćdziesiątych badacz postrzegał zestawienie alegorii i ironii jako niesłusznie zaniechany „środek prowadzący do jakichś ostrzejszych definicji, a przydałoby się to zwłaszcza ironii” (R 217). Wykład z lat siedemdziesiatych rozpoczyna się od uwagi na temat tytułu pracy Sørena Kierkegaarda - O pojęciu ironii $z$ nieustajacym odniesieniem do Sokratesa. Tytuł ten jest według de Mana ironiczny, ponieważ „ironia nie jest pojęciem”, przez co „Ustalenie definicji ironii wydaje się niemożliwe [...]" (I 252). Porównanie deklaracji wpisanych w oba teksty pokazuje zmianę, jaka zaszła w podejściu do ironii - oto $\mathrm{z}$ pojęcia przedzierzgnęła się ona w niepojęcie. Radykalizacja koncepcji ironii, zamienionej w „rodzaj kontradyktywnej figury (nie postawy, nie idei, nie pojęcia [...])” ${ }^{30}$, polega na pozornym wyprowadzeniu jej poza jurysdykcję podmiotu: „Jest to maszyneria, maszyneria tekstowa, nieuchwytna determinacja i całkowita arbitralność, unbedingter Willkür, jak mówi Schlegel [...]" (I 277). Oczywiście, ze struktury palinodii, już tu omówionej, wynika, że podjęta przeze mnie próba uhistorycznienia dorobku dekonstrukcjonisty ani nie powstrzyma, ani nie wyjaśni ironii, jest ona bowiem niczym więcej jak „włączeniem momentów ironicznych [...] w dialektykę historii” (I 261), rekomendowaną przez Georga Wilhelma Friedricha Hegla ekstrapolacją dialektyki ,ja” na proces historyczny, czyli jednym $z$ trzech opisywanych przez de Mana sposobów na jej pozorne ujarzmienie. A zatem: nie zrozumiemy nigdy.

Jednak profesor nie przerywa wykładu, nie idzie do domu, nawet więcej - zgłasza autorską definicje ironii, która jeszcze przed chwila wydawała się zupełnie niemożliwa. Posunięcia de Mana bywają nieprzejrzyste, a czasem wręcz ostentacyjnie niezrozumiałe, gdyż inscenizują samowolę języka i zapowiadają esej $O$ niezrozumiałości Schlegla, utwór, który będzie głównym tematem drugiej części wykładu. Jak zauważył Joseph Hillis Miller, dość powszechna reakcja alergiczna na pisarstwo de Mana „stanowi właśnie opór wobec tego, co w jego pracach nie jest przejrzyste, wobec półcieni niepoznawalnego, wobec niepojmowalnego, niefenomenalnego, które jest wszędzie w jego dziele” ${ }^{31}$. Opór wywołuje więc Inny (Miller czyta słowo „alergen” etymologicznie: gr. allos - 'inny'), który w późnych pismach de Mana skrywa się pod pojęciem materialności, poprzedzającej figurację, opierającej

30 W. S z t u r c, Ironia - stan po destrukcji. W: Dotkliwe przestrzenie. Studia o rytmach śmierci. Kraków 2015, s. 184.

31 J. Hilli s Mille r, Paul de Man as Allergen. W zb.: Material Events. Paul de Man and the Afterlife of Theory. Ed. T. Cohen, B. Cohen, J. Hillis Miller, A. Warminski. Minneapolis 2001, s. 198. 
się zawłaszczeniu ideologicznemu i być może odsłanianej właśnie przez defigurującą siłę ironii ${ }^{32}$.

Jedną z niezrozumiałości Pojęcia ironii wskazał Ayon Roy. Pisze on, że Kierkegaard, który zjawia się na początku wykładu jako autor „najlepszej książki na ten [tj. ironii] temat” (I 252), znika z wywodu - bez wyjaśnienia, co takiego czyni ja najlepszą - by niespodziewanie powrócić pod koniec jako bohater negatywny, piewca „historycznej dialektyki postępującej ku absolutowi” (I 279). Ramowa niespójność wzbudza podejrzenie, że dekonstrukcjonista jest na początku nieszczery i z pomocą komplementu stara się uniknąć stawienia czoła Kierkegaardowi, rzucającemu „potężne, antycypujące wyzwanie dla poststrukturalizmu de Mana” ${ }^{33}$. Oczywiście, de Man mógłby być również nieszczery w drugim momencie, trudno ostatecznie rozstrzygnąć, czy chwalił ganiąc (na początku), czy ganił chwaląc (na końcu). Kierkegaardowska rama ujawnia praktykę ironicznej komunikacji de Mana, a zwłaszcza jego nałóg, by o badaczach, których stanowisko będzie krytykował, mówić jak najlepiej: Péter Szondi to autor "godnego podziwu fragmentu” (RC 404), gdzie całkowicie rozminął się z istotą ironii, podobnie jak Jean Starobinski, który „bardzo dobrze pisał na nasz [tj. ironii] temat”, chociaż „efekt ironii wydaje się przeciwieństwem tego, co głosi” (RC 401-402).

Koncepcja Kierkegaarda rzeczywiście w Pojęciu ironii ulega elipsie, choć wcześniej, w Retoryce czasowości, temporalną strukturę alegorii de Man wiązał wyraźnie $\mathrm{Z}$,powtórzeniem (w sensie Kierkegaardowskim) poprzedzającego znaku” (RC 214). Arne Melberg w dziele Teorie mimesis odsłania subtelną relację łączącą dekonstrukcyjno-ironiczne natarcie na iluzję obecności tekstualnej z zawiłościami powtórzenia. Powtórzenie „czyni "teraz" $z$ tego, co by ł o”, jest więc „nie-pojęciem czy też pojęciem dementującym obecność, którą równocześnie sugeruje" ${ }^{34}$. Melberg widzi w powtórzeniu pomost między alegorią a ironią, a ściślej: między alegoryczną opowieścią młodzieńca a ironiczną ripostą Constantina w Powtórzeniu Kierkegaar$\mathrm{da}^{35}$. Zdaniem Roya, przemilczenie w Pojęciu ironii argumentów duńskiego filozofa stanowi ucieczkę przed konsekwencjami jego maksymy: „Na wzór negatywności ironia jest drogą: nie prawdą [...]" ${ }^{36}$. Kierkegaard mediuje między Schleglem a Heglem, który skrytykował ironię (polegającą według niego na „samounicestwieniu się tego, co wspaniałe, wielkie, wzniosłe” ${ }^{37}$ ), włączając ironiczną „iskrę szaleństwa

Wokół „prawdopodobnie najbardziej enigmatycznego słowa w Ideologii estetycznej” krążą teksty autorów antologii Material Events (s. XVI). „Materialnej inskrypcji” u de Mana i w duchu de Mana poświęcona jest również książka W a r m in s k i e g o (op. cit.). Zob. też W. H a m e r s ki, Niekończaca się opowieść. Alegorie alegorii Andrzeja Warminskiego. „Czas Kultury” 2015, nr 3.

A. Roy, Hegel contra Schlegel. Kierkegaard contra de Man. „Modern Language Association” 2009, nr 1, s. 120.

34 A. Melberg, Teorie mimesis. Repetycja. Przeł. J. Balbi e rz. Kraków 2002, s. 177, 178.

35 Wydaje się to zgodne z intuicją C. C o l e b r o o k (Irony. London - New York 2008, s. 108) dotycząca pisarstwa samego de Mana - alegoria i ironia są w nim na siebie skazane, „możemy myśleć ironicznie dopiero w następstwie wykreowania się poprzez alegorię".

36 S. Ki e r k e g a a r d, O pojęciu ironii z nieustajacym odniesieniem do Sokratesa. Przeł., posł. A. D jak ow ska. Warszawa 1999, s. 319.

37 G. W. F. Hegel, Wykłady o estetyce. T. 1. Przeł. J. Grabowski, A. Landman. Objaśn. A. Landman. Warszawa 1964, s. 114. 
bożego" 38 w dialektyczny proces, prowadzący do wypracowania koncepcji ironii opanowanej.

Ale de Man nie chce panować nad ironią, $z$ tego też powodu nie widzi możliwości sformułowania jakiejkolwiek „retoryki ironii”. Nie abstrahuje jednak całkowicie od klasycznego jej ujęcia jako tropu (lub jako figury). Tematyzacja różnicy między znaczeniami literalnym i figuralnym, czyli „świadomość figuratywności” 39 wbudowana w ironię, zdaje się nawet sugerować, iż jest ona "tropem tropów”, „paradygmatycznym odchyleniem od znaczenia dosłownego" ${ }^{40}$. Jednak perspektywa objęcia ironii klasyfikacją retoryczną pojawia się w wywodzie tylko po to, by można ją było zanegować. Umieszczenie w systemie tropów oznaczałoby „redukcję figury do gramatyki” (AC 18), próbę wyparcia faktu, że „retoryka w sposób radykalny zawiesza logikę [...]" (AC 22). Pamiętając o tym, nawet czytelnik zapisu wykładu, pozbawiony głosowych wyznaczników ironii takich jak intonacja (według klasycznego ujęcia „ironia jest figura przeznaczoną do wykonania głosowego" ${ }^{41}$ ), domyśli się, że pochwała dla Wayne’a Bootha, autora „bardzo słusznej, bardzo subtelnej, bardzo przenikliwej” (I 256) myśli o ironii zawartej w książce A Rhetoric of Irony (która przedstawia znormalizowany wzorzec ironii oraz uczy, jak ją rozpoznać w praktyce), jest pozorna. Booth postuluje „pragnienie rozumienia” jako sposób na przecięcie potencjalnie nieskończonego łańcucha ironii (metodom realizacji tego pragnienia poświęcony został osobny rozdział książki zatytułowany Learning Where to Stop ${ }^{42}$ ), który - według de Mana - nie liczy się z tym, że „ironia jest zawsze ironią rozumienia”, co oznacza, że „wiąże się z niemożliwością rozumienia” $i$ „żadne rozumienie ironii nie będzie nigdy w stanie zapanować nad ironią i jej zatrzymać [...]" (I 256). Jako taka nie może być ona, oczywiście, ani tropem, ani nawet tropem tropów ${ }^{43}$.

„Stabilna ironia” Bootha oraz „opanowana ironia” Kierkegaarda sa nieprzychylne „teutonicznej ponurości Schlegla” (określenie Bootha ${ }^{44}$ ), do której konsekwentnie przybliża się argumentacja w Pojęciu ironii. Co ciekawe, w tekście $O$ niezrozumiałości - stanowiącym autokomentarz do fragmentów z „Athenaeum”, którym zarzucano niezrozumiałość - Schlegel sam przedstawia osobliwą systematykę,

Ki er ke ga a rd, op. cit., s. 255. Mówi o tym ostatnia, XV teza jego dysertacji: „Tak jak filozofia zaczyna się od watpienia, tak godne tego miana życie człowieka zaczyna się od ironii" (ibidem).

M. Ru s in e k, Między retoryką a retorycznościa. Kraków 2003, s. 199.

Li p s zy c, op. cit., s. 150. Takie ujęcie ironii zbliżałoby ją do ujęcia H. Blooma, dla którego - jak pisze Li p s zy c (ibidem) - była ona „pierwszym krokiem samodzielnego poety”, ,paradygmatycznym odchyleniem” (clinamen), wyznaczającym początek formowania się podmiotowości twórczej. J. Zi o m e k, Retoryka opisowa. Wrocław 1990, s. 247.

42 W. C. B o o th, Learning Where to Stop. W: A Rhetoric of Irony. Chicago 1974.

43 Jako trop przedstawia ironię wszakże Markowski (Dekonstrukcja, s. 376) w podręcznikowym haśle o dekonstrukcji. Również A. Bi elik - Rob s on (Duch powierzchni. Rewizja romantyczna i filozofia. Kraków 2004, s. 221) pisze, że de Man „Przesuwa ironię w dziedzinę czysto retoryczną”, czyniąc ją „tropem tropów”. Tymczasem dla literaturoznawcy rozważanie ironii jako tropu było jedynie etapem przejściowym, przypominającym działanie bricoleura, który sięga po elementy, jakie akurat ma pod ręką. Punkt dojścia wydaje się nie tylko inny, ale wręcz sprzeczny z rozumieniem ironii jako tropu, de Man mówi o tym wyraźnie: „Ironia jest więc tak fundamentalna, że dla mnie wcale już nie jest jakimś tropem. Ironię ogólnie nazywa się tropem tropów, lecz faktycznie ironia jest naruszeniem ciagłości pola znaczenia tropologicznego" (R 248). 
pomagającą zorientować się „w całym systemie ironii”, po czym konstatuje z zadowoleniem, że można „o ironii mówić bez ironii, jak miało to właśnie miejsce”. Ale w następnym zdaniu stwierdza, że „nie sposób już z ironii wyjść, jak zdaje się to mieć miejsce w tym szkicu o niezrozumiałości [...]" ${ }^{45}$. Refleksje nie dają się uzgodnić (tylko na mgnienie oka dałoby się je zsyntezować $\mathrm{z}$ pomocą nadrzędnej ironii „zdolnej pochłaniać wszystkie inne” ${ }^{46}$ ), a sprawę komplikują ironie cząstkowe - nie wiadomo, która $z$ wypowiedzi zawiera element nie-serio (może obie? lub żadna?). Jawna paradoksalność stanowi wyzwanie dla aktu czytania ujmowanego jako rozumienie tekstu. Niezrozumiałość wynikająca z ironii nie jest dla Schlegla „czymś zdrożnym i lichym" ${ }^{47}$, a już tym bardziej dla de Mana, który z powtórzenia niezrozumiałości romantycznej czyni praktykę własnego dyskursu i kamień węgielny swojej aporiocentrycznej koncepcji języka.

Wraz z odkryciem niezrozumiałości powodowanej przez ironię badacz zyskuje narzędzie dekonstrukcji, pozostaje mu jeszcze znaleźć coś, co dałoby się dzięki temu narzędziu zdekonstruować. W tym celu de Man przeprowadza pomocniczy wywód o relacjach łaczacych teorię ironii u Schlegla $z$ Teoria wiedzy Johanna Gottlieba Fichtego. Właściwe ich opisanie było i jest przedmiotem sporów badawczych. O tym, że koncepcja ironii romantycznej sporo zawdzięcza owemu dziełu, wiedzieli już współcześni, m.in. Hegel, który dla „wirtuozostwa ironicznie-artystycznego życia” znalazł „głębsze uzasadnienie w filozofii Fichtego”, widoczne w koncepcji „samowoli Ja” nadającego znaczenia i je znoszacego ${ }^{48}$. Tomasz Ososiński twierdzi, że „specyfika recepcji pism Fichtego” polega na tym, iż „Epistemologiczne teorie zawarte w Teorii wiedzy Schlegel stosuje do opisu zjawisk o charakterze estetycznym [...]" 49 .

Nie należy jednak lekceważyć poznawczych uwikłań ironii. Można je rozpatrywać szczegółowo, tak jak Włodzimierz Szturc, gdy ukazuje nacisk kładziony na odsłanianie sztuczności świata w akcie „transcendentalnej błazenady” - deziluzji podlega nie tylko środowisko teatru (aktorzy, scena, dekoracje, widownia), ale i prawa rządzace przyrodą ${ }^{50}$, co jest zgodne $z$ prymatem ,ja” w Teorii wiedzy (wymienionej przez Schlegla - obok rewolucji francuskiej i Wilhelma Meistra - jako „wielka tendencja [...] epoki” ${ }^{51}$ ). Stosunek autora powieści Lucinde do kolegi filozofa nie był jednak ani prosty, ani niezmienny ${ }^{52}$. Ważny powód odgałęzienia się

F. S c h le g e 1, O niezrozumiałości. W zb.: Pisma teoretyczne niemieckich romantyków, s. 200 (przeł. J. Ekier). Ibidem. Ibidem. He ge 1, op. cit., s. 109, 111-112. T. O s o s iń s ki, Ironia a jednostka. Koncepcja ironii u Friedricha Schlegla i Sokratesa. Warszawa 2014 , s. 84.

Szt u r c, Ironia romantyczna, s. 111-113. J. G. F i c h te (Teoria wiedzy. Wybór pism. T. 1. Wybór, przekł., wstęp, przypisy M. J. Siemek. Aneks przeł. J. Garewicz. Warszawa 1996, s. 49, przypis gwiazdkowy) pisał: „Jakkolwiek dziwne mogłoby się to wydawać niejednemu przyrodoznawcy, to przecież w swoim czasie zostanie pokazane, że jednej rzeczy można ściśle dowieść: mianowicie tego, że to on sam najpierw wprowadził do przyrody te prawa, o których sądzi, że się od niej ich dopiero przez obserwację uczy [...]”.

Schlegel, Fragmenty, s. 82, przypis 132.

Zmagania Schlegla z Fichtem omawia szczegółowo M. Frank (The Philosophical Foundations of Early German Romanticism. Transl. E. Millán-Zaibert. Albany, N. Y., 2004, s. 192-197, 
koncepcji Schlegla od systemu Fichtego stanowiła niechęć żywiona wobec absolutyzmu pierwszych zasad (pisał Schlegel: „filozofia zawsze zaczyna się w środku, jak poemat epicki” ${ }^{53}$ ) oraz, w gruncie rzeczy, sam fakt, że był właśnie systemem (,jest równie zabójcze mieć system, jak i go nie mieć. $Z$ pewnością duch będzie musiał się zdecydować, by połączyć jedno $z$ drugim" ${ }^{54}$ ). W tym kontekście wyzywająca postawę przyjęta przez Schlegla w artykule $O$ niezrozumiałości można postrzegać ,jako praktykę oporu wobec paradygmatu, referencji i taksonomii” 55 .

Ironię romantyczną da się więc ująć jako aplikację estetyczną, rozwinięcie, przekroczenie, a w ostateczności nawet negację Teorii wiedzy Fichtego. De Man, który tyle napisał o niemożliwości domknięcia jakiegokolwiek systemu języka - retoryka zawiesza gramatykę, która dekonstruuje retorykę - podąża, oczywiście, tym ostatnim tropem, doprowadzając swoją interpretacje do granicy tego, co Gasché nazwał „idiosynkrazją w jego myśleniu”: Teoria wiedzy w ekscentrycznym odczytaniu dekonstrukcjonisty staje się teorią narracji. Badacz wychodzi od powiązania kluczowych pojęć w opisie ironii u Schlegla - autokreacji (samostworzenia), autodestrukcji (samozniszczenia) i samoograniczenia - z trzema posunięciami Fichtego, nazwanymi przez niego „całkowitej teorii wiedzy naczelnymi zasadami” ${ }^{56}$. Opisuje on „p i e r w o tny a kt”, który „tkwi u podstaw wszelkiej świadomości i jako jedyny ją umożliwia”-w wyniku tego aktu "Ja pierwotnie i bezwzględnie ustanawia swój włas ny byt" ${ }^{57}$. Abstrakcyjne, ,ja” nie jest niczym bezpośrednio danym - twierdzi de Man i dlatego interpretuje je jako „własność języka”, który je konstytuuje - ,ja” ,jest zasadniczo i nieredukowalnie językowe” (I 264) ${ }^{58}$. Przeciwieństwo „ja”, czyli „nie-ja”, także „ustanawiane bez jakiegokolwiek warunku” 59 , nie jest wynikiem dialektyki, ale równoległa koniecznością, „symetrycznym ustanowieniem [...] negacji” (I 147).

Żeby rozruszać tę zwierciadlaną strukturę, Fichte powołuje do życia trzecią zasadę naczelną, zgodnie z która „Ja, jak i Nie-ja zostają b e zw z gl ę dni e us tanowione jako ilościowo podzielne" ${ }^{60}$, co pozwala im wchodzić we wza-

205-207 n. E. Millán-Zai b e rt (Friedrich Schlegel and the Emergence of Romantic Philosophy. New York 2007, s. 18-23 n.) opisuje Schleglowski ,antyfundamentalizm poznawczy” jako wynik krytycznego przemyślenia filozofii Fichtego.

Schleg el, Fragmenty, s. 55.

Ibidem, s. 49.

M. F in lay, The Romantic Irony of Semiotics. Friedrich Schlegel and the Crisis of Representation. Berlin - New York 1988, s. 193.

Fich te, Teoria wiedzy, s. 83.

Ibidem, s. 83, 92.

Bielik-Robson zauważa, że uczynienie ,ja” własnością języka jest u de Mana możliwe za sprawą pominięcia w wywodzie pojęcia „intelektualnego oglądu”: ,jest to bezpośrednia świadomość tego, że działam i jak działam” - mówi Fi ch te (ibidem, s. 510) i nadmienia: „za pomoca pojęć nie da się wykazać, że istnieje władza takiego oglądu intelektualnego [...]. Każdy musi odnaleźć go bezpośrednio w sobie samym, inaczej nie pozna go nigdy" (ibidem, s. 511). Bi eli k - Ro b s o n (op. cit., s. 222) dostrzega w oglądzie nie językową, ale fenomenologiczną „apodyktyczną pewność”, której „absolutnie nie sposób sparafrazować [...] w manierze czysto retorycznej”. Na brak tego pojęcia w wywodzie de Mana zwrócił również uwagę Roy (op. cit., s. 111 n.).

Fich te, op. cit., s. 99.

Ibidem, s. 107. 
jemne relacje opisywane przez Fichtego jako możliwość ograniczania się, bez potrzeby unicestwiania w całkowitej negacji. Dzięki temu ,ja” i „nie-ja” zyskują cechy, które można porównywać np. pod względem podobieństwa (sądy syntetyczne) czy różnic (sądy analityczne), pojawia się zdolność autorefleksyjnego ustanawiania równości (sądy tetyczne). Ta cyrkulacja cech musi odwoływać się do pojęć wyższego rzędu (Fichte podaje przykład relacji metalu do srebra i złota) lub niższego rzędu (np. w syntetycznym ujęciu ciał pomija się różnice, takie jak ich ciężar czy kolor). Części odnoszą się do całości, całości zaś do części, podobieństwa zakładają istnienie różnic, a różnice istnienie podobieństw. Owo krążenie cech kojarzy się de Manowi $z$ tropami:

jest strukturowane jak synekdocha, relacja między częścią i całością, lub strukturowane jak metafora, zamiana na podstawie podobieństwa i różnicy między dwoma bytami. [I 269]

Filozofia podmiotu, która odegrała tak ważną rolę w formowaniu się koncepcji ironii romantycznej, okazuje się zatem teorią figuracji ufundowaną na performatywie, czyli pierwotnym ustanowieniu ,ja” poprzez akt. Sposób, w jaki opisuje to Fichte, wydaje się „wysoce systematyczny”, stanowi spójną opowieść o wyłanianiu sie ,ja”, ale to opowieść, której głównym celem jest przedstawienie narratologicznego mechanizmu ją wytwarzającego (Schlegel stwierdza w Liście o powieści: „teoria powieści sama musiałaby być powieścia [...]”61), dlatego de Man nazywa ją alegorią: system „Jest alegorią, narracją opowiadającą o interakcji między tropem a performancją" (I 270). Tak jak nie jest możliwy skończony system tropów, tak niemożliwe okazuje się ostateczne ustabilizowanie narracji na temat ,ja” ze względu na nieustająca zwrotną i refleksyjną relację $z$ „nie-ja”.

Nietrudno zgadnąć, jakie zadanie przypisuje de Man ironii w odniesieniu do tego systemu - ma go zniszczyć. Odwołania Schlegla do „maniery mimicznej zwykłego, dobrego włoskiego buffo”, ,transcendentalnej błazenady”, ,ciagłej autoparodii” czy „nieustającej parabazy” mają czytelne konotacje teatralne i w estetycznej wykładni ironii romantycznej zostają wyrażone za pomoca konkretnych posunięć artystycznych, takich jak „wychylanie się autora $z$ kart tworzonego dzieła” czy „popisy artysty-linoskocza”, który „utrzymywał świat będący przedmiotem komentarza w dziwnym zawieszeniu" ${ }^{2}$. Według de Mana estetyczne ujęcie tematu jest redukcjonistyczne, ponieważ karmi się iluzją dotyczącą możliwości okiełznania ironii poprzez definicje, opisania jej reguł i odgrodzenie w tekście miejsc, w których się ujawnia. Widzimy w tym pewną ironię, ponieważ jej żywioł stanowi właśnie deziluzja, mająca dla dekonstrukcjonisty poważne konsekwencje epistemologiczne. W wykładzie de Man wyjaśnia to poprzez zaakcentowanie definicji ironii jako „permanentnej parabazy" (innym określeniem na parabazę byłby anakolut, oznaczający zaskakujący zwrot w składni zdania): „Zatem buffo jest parabazą lub anakolutem, przerwaniem ciagu narracyjnego, wypracowanej arabeski lub watku stworzonego przez Fichtego" (I 273). Parabaza okazuje się paradoksalna, ponieważ jest permanentna (tak jakby możliwy był nieustający zwrot w stronę publiczności lub nieprze-

61 Schlegel, Rozmowa o poezji, s. 175.

62 Sztur c, Ironia romantyczna, s. 188, 166, 187, 190. 
rwane zdejmowanie maski w czasie trwania całej sztuki), co de Man rozumie jako ciagłe zagrożenie dla każdej narracji, nawet jeśli ma ona stanowić teorię narracji (jak jego własna): „ironia jest wszędzie, we wszystkich punktach” (I 273).

Stosunek Schlegla do Fichtego staje się jasny - ironia nie jest powtórzeniem, rozwinięciem czy przekroczeniem teorii wiedzy, ale jej zniweczeniem („ruptured”, „interrupted”, „disrupted” - to określenia, które powracaja w opisie de Mana), ironia „niweczy wszelką narracyjną spójność wywodów [...]” (I 277), niszczy dialektykę dzięki zdolności zaprzeczania fałszywym syntezom, rozrywa system tropologiczny, pokazując niemożliwość jego domknięcia. Oczywiście, ironia nie dekonstruuje tylko wątku Fichtego, który pozwolił jej się ujawnić, ale dotyczy wszystkich narracji, co ułatwia de Manowi dopełnienie Schleglowskiej definicji: „ironia to permanentna parabaza alegorii tropów" (I 274). Oto zapowiedziana jako niemożliwa, definicja pojęcia ironii (która nie jest pojęciem). Sama ta definicja wydaje się już mininarracją, streszczająca podstawowe i powracające wyobrażenie de Mana o języku: „Na wzorzec wszelkich tekstów składa się figura (lub system figur) i jej dekonstrukcja” (AC 246). Jako narracja definicja ta jest podatna na zerwanie (ironizację), może więc lepiej byłoby ją nazwać alegorią definicji - alegorią niemożliwej definicji niepojęcia ironii.

A zatem de Man po raz kolejny „odnajduje siebie w przedsięwziętej próbie analizy":

ironia jest dokładnie tym, co uniemożliwia uzyskanie spójnej teorii narracji. Nie oznacza to, że nie powinniśmy dalej nad tym pracować, ponieważ tylko to możemy robić [...]. [I 274]

Można by przyjąć, iż „my” jest sytuacyjne (i odnosi się raczej do słuchaczy, którzy już wiedzą, że „Nie zrozumieją [...] nigdy [...]”), ale myśl o niemożliwości wyłamania się $z$,pozorów przewrotności i obłędu lub bezmyślności i głupoty” ${ }^{63}$, czyli wykroczenia poza niezrozumiałość ironii bez wycofania się $\mathrm{w}$ iluzję narracji (,języka autentycznego”, używając określenia Schlegla, a więc mitologii, będącej dla de Mana odpowiednikiem tego, co sam nazywał ideologia ${ }^{64}$ ) nieustannie odradza się.

Lektura Pojęcia ironii nie powinna prześliznąc się po takim oto zdaniu: „Oczekiwanie, jakie ktoś mógłby żywić, że dekonstrukcja mogłaby być zdolna do konstrukcji, jest zawieszone przez taki fragment [...]" (I 280). To zaskakująca zmiana tematu, ponieważ passusem, do którego odnosi się badacz, jest Schleglowska apologia niezrozumiałości („Odrobina niezrozumiałości wystarczy; byle dochować ją czysto i wiernie [...]"65). De Man na początku wykładu informował, że będzie on dotyczył teoretycznego ujęcia ironii we wczesnym romantyzmie niemieckim (a nie dekonstrukcji!), i - przy odrobinie wyrozumiałości dla żywiołowych dygresji - można uznać, że tak było. Zacytowane zdanie, pozwalając odkryć, że tekst o Schleglu to również tekst o de Manie, staje się inscenizacją niespodzianki składniowej, którą chwilę wcześniej nazwano anakolutem czy parabazą l,zamiast spełnienia 
oczekiwań w kategoriach budowanej składni otrzymuje się coś zupełnie innego [...]”, I 272). Przykładem „permanentnej parabazy” w Pojęciu ironii jest Refleksja, rozdział z powieści Schlegla Lucinde, w którym spod filozoficznego wywodu, operującego terminologia Fichtego, przeziera opis igraszek erotycznych: „Piszą Państwo wspaniała i koherentną argumentację filozoficzną, aż tu nagle opisuja państwo stosunek płciowy" (I 277). Piszesz o ironii w niemieckim romantyzmie, aż tu nagle okazuje się, że opisujesz dekonstrukcję, dostrzegasz „swą własną postać” widoczną „pośród innych figur”.

Ironia i teoria zaplataja się w wykładzie de Mana w skomplikowany węzeł. W Retoryce czasowości ,ja” wpada w dialektyczną pułapkę lustrzanych odbić, która doprowadza do „kresu wszelkiej świadomości” (R 226). Punktem wyjścia jest więc jakiś podmiot, który pod wpływem ironii rozdwaja się, po czym rozdwaja się, po czym rozdwaja się, co ostatecznie doprowadza do jego zniknięcia. W Pojęciu ironii, które stanowi sequel artykułu Retoryka czasowości, roztacza się pejzaż postapokaliptyczny, po tradycyjnie rozumianym podmiocie nie ma już śladu. Ironia jako parabaza alegorii „przestaje być ruchem świadomości, a staje się niesforną właściwościa języka" ${ }^{66}$, która niweczy trop, sekwencję tropów w postaci narracji i odczytanie tej narracji w formie alegorii.

"Radykalne odpodmiotowienie ironii”, jak to ujmuje Agata Bielik-Robson ${ }^{67}$, powoduje repozycję w relacji ironia-alegoria. W Retoryce czasowości alegoria dzieje się w języku (daje narracyjny efekt rozciagłości nie istniejący w doświadczeniu), ironia zaś przydarza się podmiotowi (różnica zawarta jest w ,ja”), jednak obie stanowią wynik tego samego doświadczenia temporalnego, przeciwstawionego fałszowi symbolu czy mimesis. Alegoria wydaje się fabularna wersją ironii albo jej malarskim rozprowadzeniem na płótnie czasu. W Pojęciu ironii alegoria i ironia nie sa już dwoma „trybami” działającymi równolegle na rzecz demistyfikacji językowych iluzji, ale współtworzą samozwrotną strukturę języka, decydującą o tym, że żadna narracja nie może się serio ukonstytuować. Wolno na to spojrzeć optymistycznie: opowieść, będąca przecież metaforą życia, jest nieskończona, ironia nie pozwala wyświetlić ostatniej klatki $z$ napisem „Koniec” ${ }^{68}$. „Permanentna parabaza” narusza

Lip szy c, op. cit., s. 149.

Bielik-Robs on, op. cit., s. 221.

68 Na aspekt wolności wpisanej w ironicznie bajkowa „nie kończącą się opowieść” nacisk kładzie J. Hilli s Miller (Reading Narrative. Norman, Okl., 1998, s. 227-230 n.). Można z tej perspektywy spojrzeć na bajkę Klingsohra opowiadaną w dziewiątym rozdziale powieści Novalis a Henryk von Ofterdingen (s. 144):

$$
\begin{aligned}
& \text { Ja przęde wasze nici } \\
& \text { I łacze } w \text { j ed n a nić. } \\
& \text { Już koniec nienawiści, } \\
& \text { Więc j e d n ia macie być. } \\
& \text { Przez je d n o życia tchnienie } \\
& \text { We wszystkim wszystko żyje, } \\
& \text { I jed n o jest istnienie, } \\
& \text { Gdy je d no serce bije. }
\end{aligned}
$$

Koncyliacyjna piosenka upersonifikowanej Bajki, powołująca do życia symboliczną jednię, może być nacechowana, jak zauważaja autorzy wstępu do cytowanego wydania, „prostotą ironiczną" (Novalis, op. cit., s. XC). Symboliczna utopia narracyjna (opowieść „się przędzie”) jako „tylko” 
dialektyczne modele narracyjne, takie jak historia literatury, stanowi więc również zagrożenie dla próby diachronicznego opisu ironii w myśli de Mana.

Powracamy zatem do samokrytyki z początku wykładu. Narrację na temat przejścia od rozumienia ironii jako dialektyki ,ja” do cokolwiek posthumanistycznego ujęcia jej jako „maszynerii tekstowej” można zironizować, a jednak dekonstrukcjonista sam się - by tak rzec - diachronizuje: demistyfikując fałszywe założenie, jakie kiedyś przyjął (że ironia to dialektyka podmiotu), równocześnie demistyfikuje tę demistyfikację (jako naiwną próbę uhistorycznienia siebie samego poprzez analogiczną dialektykę). Ostatecznie nie wiadomo więc, czy de Man odwołuje swoje wcześniejsze poglądy, czy ich nie odwołuje, coś mówi, czy nie mówi zgoła niczego, starając się tylko „czysto i wiernie” przechować „odrobinę niezrozumiałości” z tekstu Schlegla.

\section{Zero ironii}

Jeżeli „ironia jest wszędzie, we wszystkich punktach [...]”, to nawet najbardziej zdyscyplinowane wywody, odwołujące się do niezawisłego autorytetu języka formalnego, nie są zdolne jej wytrzebić. De Man przekonuje o tym w Pascalowskiej alegorii perswazji, artykule ujawniającym interferencje myślenia matematycznego i religijnego w twórczości Blaise'a Pascala. Dekonstrukcjonista czyta Rozważania ogólne nad geometria jako próbę formalnego umocowania projektu teologicznego, zrealizowanego głównie w Myślach. Problem polega na tym, że projekt ów chce uzgodnić trudne do uspójnienia właściwości rzeczy, których „poznanie przybliża umysł do największych cudów natury” ${ }^{69}$. Przede wszystkim „Trzy rzeczy, w których zamyka się cały wszechświat - wedle słów: "Deus fecit omnia in pondere, in numero et mensura" - połaczone są wzajemnym [...] związkiem"70. Związek ów, ustanowiony przez Boga, to zasada homologii ruchu, liczby, przestrzeni, a właściwie również i czwartej „rzeczy”, czyli czasu. Innymi wrotami prowadzącymi nas ku „cudom natury” jest zasada dwóch nieskończoności: wielkości i małości. Te „przedziwne nieskończoności” natura „postawiła ludziom przed oczy nie po to, by je pojęli, lecz po to, by się nimi zdumiewali”71. A zatem, po raz kolejny: „Nie zrozumiemy [...] nigdy [...]”. Pierwotna niepojmowalność stanowi temat wielu aforyzmów w Myślach, ukazujących małość człowieka „zawieszonego w masie, jaką natura mu dała między tymi dwiema otchłaniami, Nieskończonością i Nicością"72, ale w wywodzie de Mana niepojmowalność ta jest również przekładalna na Schleglowską niezrozumiałość, czyli ironię.

Pascala interesuje „kwestia dowodzenia prawd już wykrytych” ${ }^{73}$, więc kluczowe

bajka, opowieść w opowieści, ironicznie dystansuje się od ewentualności splecenia się porządków językowego i fenomenalnego, które mogłoby być rzekomo punktem dojścia w procesie kształcenia (Bildung) Henryka. Bajka stanowiłaby wtedy kolejny synonim mitologii (,języka autentycznego”) Schlegla lub „ideologii estetycznej” de Mana.

B. P a s c a l, Rozważania ogólne nad geometria. W: Rozprawy i listy. Przeł. T. Że leńs ki - B oy,

M. Ta zbir. Wybór, przedm., przypisy M. Tazbir. Warszawa 1962, s. 127.

Ibidem, s. 126.

Ibidem, s. 137-138.

B. Pa s c a l, Myśli. Przekł. T. Żel eń ski (B oy). Poznań 1921, s. 20.

P a s c a l, Rozważania ogólne nad geometria, s. 115. 
są dla niego sposoby przekonywania o prawdziwości tych prawd, co tłumaczy połączenie dwóch rozpraw w jedną: O metodzie dowodzeń geometrycznych oraz $O$ sztuce przekonywania. Miejsce, gdzie krzyżują się porządki epistemologiczny i retoryczny, przykuwa uwagę de Mana, który śledzi ekwilibrystykę Pascala retorycznie (topos skromności) odżegnującego się od retoryki (odwołania się do serca, nie do rozumu), podobnie jak robił to w Epistemologii metafory, gdy opisywał potępienie zwodniczej retoryki w teorii poznania Johna Locke’a: „Trudno o bardziej krasomówcze potępienie krasomówstwa" (I 47).

Prawdziwe problemy zaczynają się jednak, gdy Pascal przypomina rozróżnienie na definicje słowne (nominalne) i rzeczowe (realne) - te pierwsze sa pewne, polegają na nadawaniu nazw „za pomocą doskonale znanych terminów” i dlatego powinny być jedynym narzędziem geometry (czyli matematyka - Pascal wymienia jako przykład definicję liczby parzystej), podczas gdy drugie, odnosząc się do cech przedmiotów, skażone są referencją. Oczywiście, ,aberracja referencjalna” (AC 22) znajduje sposób, by wkraść się w nominalną utopię. Słabe ogniwo stanowią terminy pierwotne, jedyne, które nie muszą być definiowane, bo rozumieją się same przez się dzięki „światłu naturalnemu”, a ich objaśnianie „więcej by zaciemniało, niż wyjaśniało" ${ }^{74}$. Nie można podać nominalnej definicji pojęcia czasu, ale słysząc wyraz „czas”, „wszyscy kieruja myśl ku temu samemu przedmiotowi” ${ }^{75}$. De Man wskazuje, że termin pierwotny funkcjonuje jako trop: „znak stał się tropem, relacją zamiany [...]” (I 79), wyrażaną figura „kierować myśl”. Definicja terminu pierwotnego jako niedowodliwa sama staje się terminem pierwotnym. W dodatku „definicja definicji nominalnej sama jest definicją realną, a nie nominalną" (I 79), ponieważ zbudowana jest przez relację do definicji realnej, zawiera więc odniesienie do czegoś poza królestwem nazw. System wydaje się od początku - jak to ujmuje Warminski - „skażony, zarażony definicjami re alny mi”76.

Kolejny problem w narracji Pascala pojawia się wtedy, gdy ma on pogodzić zasadę dwóch nieskończoności $z$ wielką analogią między czasem, przestrzenią, liczbą a ruchem. De Man streszcza XVII-wieczne polemiki, wskazujące na niemożliwość uzgodnienia koncepcji nieskończonej małości z ideą correspondances łącząca porządki przestrzeni, ruchu, czasu i liczby. Problem stanowi status jedynki, która nie jest liczbą (ale pojedynczością, brakiem liczby, jej mnożenie przez siebie nie przynosi efektu), choć równocześnie jest liczbą (uczestniczy w nieskończoności na zasadzie synekdochy, tak jak pojedynczy dom nie równa się miastu, lecz współtworzy miasto). Wielka ekwiwalencja załamuje się, ponieważ zwielokrotnianie niepodzielników czasu (teraz) czy ruchu (spoczynek) - inaczej niż jedynki - nie daje żadnego efektu. Na ratunek „boskiemu porządkowi” analogii Pascal posyła zero, które w świecie liczb stanowi odpowiednik spoczynku i momentu w dziedzinie ruchu i czasu. Zero jako (nie)liczba było przedmiotem filozoficznych polemik od starożytności ${ }^{77}$, dla Pascala liczbą nie jest (bo nie może stać się większe od innych

Ibidem, s. 120-121.

Ibidem, s. 122 .

A. W a r min ski, Alegorie referencji. Wstęp w: I 33.

Polemiki te streszcza, w kontekście de Mana i innych literaturoznawczych aplikacji koncepcji zera, J. Hillis Miller (Three Literary Theorists in Search of 0. W zb.: Provocations to Read- 
liczb poprzez mnożenie). Koherencję systemu przywraca element, „który sam jest całkowicie heterogeniczny w odniesieniu do tego systemu”, ciąłość wszechświata zostaje więc „przerwana, naruszona we wszystkich punktach przez zasadę radykalnej heterogeniczności [...]" (I 83). A zatem to, co uszczelnia system, zarazem go niweczy, narracja teologiczna, asymptotycznie zbliżająca się dzięki figuralnym przekształceniom (dom-miasto, las-drzewo) do biegunów nieskończoności, znajduje swojego Innego pod postacią zera. Zero przerywa składnię wywodu, stanowi więc coś w rodzaju anakolutu (parabazy), odpowiednika Schleglowskiej ironii w myśli Pascala.

\section{Konkluzja de Mana jest następująca:}

Nazywanie tej struktury ironiczną może być bardziej mylące niż pomocne, skoro i r o n ia, tak jak z e r o, jest terminem, który nie poddaje się nominalnej czy realnej definicji. Powiedzenie zatem, tak jak faktycznie mówimy, że alegoria (jako narracja sekwencyjna) jest tropem ironii (tak jak jedynka jest tropem zera), jest powiedzeniem czegoś, co jest wystarczająco prawdziwe, ale nie jest zrozumiałe, co również implikuje, że nie może być ona uwzględniona jako narzędzie analizy tekstowej. [I 86]

Fragment ten prowokuje pytania: opisana struktura ostatecznie zostaje czy nie zostaje nazwana ironiczną? Coś „faktycznie mówimy” czy jednak nic nie mówimy, skoro nie wiemy, czy rozumiemy, czy nie rozumiemy? Oczywiście, de Man, jako zwolennik romantycznego stylu myślenia, zakłada, że niezrozumiałość nie jest czymś „zdrożnym ani lichym” - może należałoby ją po prostu „czysto i wiernie” przechować. Przecież samego Pascala, co chyba umyka dekonstrukcjoniście, dopada na chwilę nieco schleglowski nastrój (tyle że o podłożu jednoznacznie teologicznym), gdy filozof korzy się przed niezrozumieniem, związanym z niemożliwością objaśnienia terminów pierwotnych - człowiek „zawsze skłonny jest przeczyć wszystkiemu, czego nie rozumie”, podczas gdy niekiedy trzeba uznać fakt, „nie bacząc na jego niezrozumiałość"78. Wykład de Mana, podobnie jak wywód Pascala, stanowi - parafrazując słowa dekonstrukcjonisty - „raczej alegorię niż dowód” (zob. I 77), ponieważ, nie pierwszy raz, uwewnętrznia w narracji ironię, o której opowiada. W gramatycznym sensie niczego nie nazywa (ledwie orzeka coś nieprzychylnego o nazywaniu: „nazywanie... może być”), ale jednak robi to, czego nie nazywa (tak jak robi to pośredni akt mowy). Ponadto, co podkreśla Warminski, z pomoca dziwnej nadwyżki tematyzuje sam akt mówienia (,powiedzenie, jak faktycznie mówimy”), dokonujac parabazy „samopowielającej się siły wypowiadania jedynie mówienia”79, a zarazem powtórzenia, które może oznaczać - czego z kolei obawia się Melberg utknięcie w „pułapce lustra”, nieskończonej reprodukcji odbić, przypominającej

ing. J. Hillis Miller and the Democracy to Come. Ed. B. Cohen, D. Kujundžić. New York 2005).

78 Pa s c a 1, Rozważania ogólne nad geometria, s. 130. Filozof pisze też:

„Wydaje się zatem, że ludzie z natury są i będą niezdolni ując jakąkolwiek naukę w system bezwzględnie doskonały.

Nie znaczy to jednak, że mamy się wyrzec wszelkiego systemu" (ibidem, s. 120).

Z myślą tą rezonuje aforyzm S c h le gl la (Fragmenty, s. 49) o potrzebie i niemożliwości posiadania systemu.

79 W a r min s ki, op. cit., s. 40. Autor zwraca też uwagę, że błędne przestankowanie („To say then”) „wzmacnia tylko szaleństwo tego mechanicznego powtarzania” (ibidem). 
jąkanie się, czystą iterację odrywającą się od „ruchu lirycznego” Kierkegaardowskiego powtórzenia ${ }^{80}$.

Treść zacytowanych konkluzji de Mana jest równie osobliwa jak forma, skoro trzeba pomyśleć porządek liczby jako system tropów rozrywany przez zero... Okazuje się to „wystarczająco prawdziwe, ale nie jest zrozumiałe [...]”, mówi de Man. Zero nie może być tropem, ponieważ nie jest pojęciem (jak zatem ma stać się terminem?), czyli nie podlega definicji nominalnej (jest podrzutkiem w zamkniętym systemie liczb - jest innego rodzaju) ani realnej (do niczego się nie odnosi). W systemie „pojawia się w przebraniu j e d y n k i [...]” (I 84), czyli - jak zauważa w swoim komentarzu Hillis Miller ${ }^{81}$ - jako katachreza, nazwa nadana $z$ konieczności czemuś, co nazwy nie ma. Zero należy traktować raczej jako coś niż jako nic, by zamaskować rozdarcie, które wprowadza do systemu liczb, inaczej niż paradoksalna jedynka, stanowiąca nazwę nadaną bytowi pozbawionemu liczby (jako „nominalna definicja nieliczby"). Z jedynek można już coś ułożyć, np. progresywną narrację teologiczną, dowolnie długą. Ironii natomiast nie da się pojąć (zdefiniować), choć można ją przedstawić za pomoca alegorii - „Narracja jest metaforą chwili [...]” (AC 86) - jest niczym zero, które skrywa się pod narracyjnym płaszczykiem jedynki. System domaga się „zatarcia zera” (I 84), czyli zamaskowania Innego, który sieje ironiczny zamęt w homogenicznym świecie liczb.

W rozumieniu de Mana każda próba totalizacji sensu - może to być teologiczna koncepcja, ale również symboliczny obraz poetycki - ma swój moment heterogeniczny, ironiczne „zero oznaczania” (I 83), i próbuje je zamaskować poprzez przydanie mu figury, twarzy, założenie maski jedynki. Dobrą ilustracją tej zero-jedynkowej struktury, stanowiąca równocześnie przejście między jawnym a ukrytym trybem funkcjonowania ironii w pracach de Mana, jest należacy do grupy ostatnich jego artykułów Antropomorfizm i trop w liryce. Mniej więcej w połowie tekstu natrafiamy na krótką wzmiankę o Pascalu - całkowicie niezrozumiałą dla czytelników niezaznajomionych $\mathrm{z}$ argumentacja $\mathrm{z}$ Pascalowskiej alegorii perswazji - i o jego „poskramianiu liczb” przez „przywrócenie jedynki” (AT 131).

Większość szkicu poświęcona jest lekturze dwóch utworów Baudelaire’a - de Man czyta Odpowiedniki jako podtekst (hipogram) późniejszego wiersza Obsesja. Oba sonety istotnie wchodza $\mathrm{w}$ relację (drugi wydaje się pod wieloma względami odwróceniem pierwszego), z której literaturoznawca jak zwykle wyprowadza ogólną zasadę organizującą czytanie, „uczynnie wskazaną” przez poetę. Gdy de Man powiada: „Sa zawsze [...] dwa teksty, bez względu na to, czy zostały one napisane [...]” (AT 143), ponownie ociera się o niezrozumiałość. Można jednak przystać na to stwierdzenie, jeżeli zgodzimy się potraktować dialog między utworami jako metaforę czytania (Obsesja stanowiłaby odczytanie Odpowiedników, a nie odwrotnie nawet gdyby kolejność napisania wierszy była inna), polegającego na uczynieniu zrozumiałym tego, co takim nie jest, nie jest zaś w pełni zrozumiały sonet Odpowiedniki. Wiersz opisuje wędrówkę przez "las symboli” (cyt. AT 11782) i łatwo może być interpretowany jako manifest symboliczny, konsekwentnie realizujący ideę

Hillis Mille r, Three Literary Theorists in Search of 0, s. 225.

Wiersz Ch. B a u d ela ir e' a Odpowiedniki, w tłumaczeniu J. W a c zkó w. 
przyległości między bytami (tytułowe correspondances) poprzez serię figuralnych analogii zmierzających do antropomorfizmu (kolumny-drzewa ,jakieś niezrozumiałe słowa szepczą”, cyt. AT 145 ${ }^{83}$ ) i doskonałych odpowiedniości („Odpowiadaja sobie wonie, barwy, tony", cyt. AT 145).

De Man odkrywa, że „symbolistyczna ideologia wiersza” podszyta jest „aberracja” (AT 130), którą wprowadza aporia związana z funkcjonowaniem zaimka ,jak”. Niemal przez cały sonet udaje mu się zachować efektywność symboliczną (dzięki synestezji: zapachy sa „świeże jak ciałka dziecinne”, „dźwięczne jak flet”, „zielone jak łąki” 〈Odpowiedniki, AT 26〉), która jednak znika przy ostatnim użyciu ,jak” ze względu na jego podwójne odniesienie - do „nieskończoności skrzydeł” oraz ponownie do „zapachów”. Pierwsze $z$ nich podtrzymywałoby dynamike symbolicznego „uniesienia” (słowo „transports” tematyzuje ruch sensów etymologicznie zapieczętowany w słowie „metaphorein”), jednak drugie sprawia, że „Zamiast analogii mamy wyliczankę [...]” (AT 131), ,jak” zatraca zdolność „transportującą”, a zaczyna znaczyć „takie jak”: „są zapachy [...] / Jak wonie ambry, piżma, żywicy, kadzidła”... (Obsesja, AT 27). Niemożność rozpoznania właściwego odniesienia powoduje, że wiersz jest permanentnie zagrożony tautologią: „cóż mogłoby być bardziej perwersyjne lub gorszące dla metafory dążącej do transcendentalnej totalizacji niż utkwienie w wyliczaniu, z którego nie ma wyjścia”? (AT 131). Przeciwko perwersji „macierzystego tekstu pozbawionego sensu” ${ }^{84}$ występuje wiersz Obsesja, który „ucieka się do syntezy, niknąc w niejasnościach nieskończoności” (AT 142).

Jeżeli operacja - dokonana w Obsesji, stanowiącej odczytanie Odpowiedników - nazwana zostaje „przywróceniem jedynki”, to widzimy wyraźnie, że oto ironia, chociaż nie przedstawiona $\mathrm{z}$ imienia, zjawia się $\mathrm{w}$ argumentacji Antropomorfizmu $i$ tropu $w$ liryce. Potrzeba bowiem „systematycznego zatarcia zera”, aby wyjść z tautologii bezsensownej wymienianki $(0+0+0 \ldots)$, niezbędne jest „przebranie jedynki”, aby ruch w nieskończoność mógł trwać $(1+1+1 \ldots)$. Odpowiedniki nie dają żadnej wskazówki pozwalającej rozstrzygnąć syntaktyczną pozycję ,jak”, konieczne okazuje się więc „błędne liryczne odczytanie tego, co niezrozumiałe” (AT 144). Podtrzymuje ono „symboliczną narrację" wiersza poprzez elipsę „zakłócenia powierzchni syntaktycznej” (AT 124), zwanego w Pojęciu ironii anakolutem - czyli poprzez stłumienie ironii Odpowiedników za pomoca „, huczenia kniei” i „ryku oceanu” (Obsesja, AT 27), głośnej retoryki Obsesji ${ }^{85}$. mogą być traktowane jako ironiczne krzyżujac to odczytanie $z$ wnioskami ze znacznie wcześniejszego tekstu de Mana Struktura intencjonalna obrazu romantycznego. Przedmiotem in-
terpretacji w tym artykule była m.in. elegia Chleb $i$ wino F. Höld erlina, w którą również wpisany jest totalizujący projekt poetycki: „Teraz muszą rodzić się słowa, jak rodzą się kwiaty” (SI 311). De Man zauważa, że ,jak” w porównaniu obnaża nierealność aspiracji języka poetyckiego do zrównania się z obrazem naturalnym, wprowadzając świadomość różnicy: „Wszelki początek możemy ujmować w kategoriach różnicy [...]”, ,Z samej istoty języka wynika [...] niemożność dokonania [...] absolutnej identyfikacji z samym soba [...]” (SI 310, 311). „Comme” w wierszu Baudelaire’a, podobnie jak „wie" w wierszu Hölderlina, odsyła do czasowej otchłani, odsłanianej w Retoryce czasowości przez alegorię i ironię. Podobną w stylu dekonstrukcję romantycznego „obrazu naturalnego" przeprowadza P. de Man w eseju Landscape in Wordsworth and Yeats, dochodząc do wniosku, że

Można rozszerzyć tę interpretację, wykazując, że nie tylko ostatnie, ale wszystkie poprzednie „jak” http://rcin.org.pl 


\section{Ironia a tergo}

W Alegoriach czytania Schlegel wzmiankowany jest ledwie kilkakrotnie, ale przynajmniej raz w miejscu eksponowanym, mianowicie na ostatniej stronicy, w ostatnim akapicie. Ironia stanowi dla książki punkt dojścia, z którego wysokości można przyjrzeć się jej wcześniejszym rozdziałom. Lektura wsteczna, biegnąca pod prąd narracji - do której zachęca konstrukcja tytułu, będąca niemal dokładnym odwróceniem spisu treści - pozwoli na „rekapitulację ujawnienia ironii w przebraniu skrywania” (AC 339), jeżeli można dokonać takiej suplementacji cytatu odnoszącego się w Alegoriach czytania do Rousseau, nie do de Mana.

W Wyznaniach przyciaga badacza owa niejasna scena, w której Jean Jacques kradnie wstążkę, a po odkryciu kradzieży rzuca oskarżenie na niewinną Marion. Bohater twierdzi, iż to ze względu na tajoną sympatię oskarżył dziewczynę o kradzież, co brzmi niedorzecznie, dopóki nie uświadomimy sobie, że wstążka jest „czystym znaczącym”, „krążącym symbolicznie [...] w łańcuchu zamian i posiadania” (AC 336):

Pożądanie pojmowane jako posiadanie pozwala na kluczowe wprowadzenie przemieszczenia figuralnego: rzeczy nie są po prostu tym, czym zdają się być, wstążka nie jest po prostu wstążką, kradzież może być aktem miłości, akt spełniony przez Rousseau może zostać przypisany Marion i w procesie tym staje się on raczej bardziej niż mniej zrozumiały etc. [AC 338]

Na odsłonięciu języka figuralnego, niestrudzonego pośrednika, nie pozwalającego konfesjom Rousseau osiagnąć „przejrzystości kryształu”, de Man jednak nie poprzestaje. Spoistość symbolicznego „łańcucha zamian i posiadania” zostaje osłabiona przez niespodziewane wyznanie. Ciagnie Jean Jacques: „zaskoczony, oparłem swoje usprawiedliwienie o pierwszy przedmiot, który się nasuną" 86 . Zdanie odwołujące się do „słownika przypadkowości” (AC 342) narusza składnię usprawiedliwienia, pozwalając „na całkowity rozdział pomiędzy pożądaniem Rousseau i jego interesami a wyborem tego szczególnego imienia” (AC 343).

Marion w rozumieniu de Mana nie może być jednocześnie przedmiotem pożądania i „przedmiotem, który się nasunął”. Jeśli tak się dzieje, usprawiedliwienie z zawoalowanego, lecz tropologicznie spójnego wywodu zamienia się w arbitralny akt: „Separacja między podmiotem a wypowiedzią jest [...] tak radykalna, że wymyka się wszelkiemu zrozumieniu" (AC 343). Obcy element, przerywający narrację o skrywanym pożądaniu, to anakolut lub parabaza. W ostatnim akapicie Alegorii czytania to „zdarzenie tekstowe” ukazuje się pod rozpoznawalna postacia ironii, będącej „zniweczeniem dekonstrukcyjnej alegorii wszelkich poznań tropologicznych czy też systematycznym niweczeniem rozumienia” (AC 357). Tak jak Marion musi zostać oskarżona, by „dostarczyć [...] dobrego zakończenia II księgi [...] Wyznań” (AC 339), tak również ironia dostaje efektowną scenę ujawnienia, by dostarczyć

„poematy uwodzą urokiem zmysłowym swoich naturalnych pejzaży i obrazów, podczas gdy uzyskanie głębszej strukturalnej jedności oraz większość ich zawartości intelektualnej zależy od nienaturalnego albo nawet antynaturalnego użycia języka” (RR 143).

86 J. J. Rous seau, Wyznania. Przekł., wstęp T. Żeleński (Boy). Przedm. E. Rzadkowska. Cz. 1. Warszawa 1956, s. 159. 
mocnego zakończenia Alegoriom czytania. Analogiczną, choć o wiele bardziej subtelną podwójność kodowania odkrywa w tej scenie Barbara Johnson. Zdanie, w którym de Man opisuje działanie anakolutu, eliminującego pożądanie i podmiot, by postawić w jego miejscu „absolutna przypadkowość języka” (AC 355), samo jest anakolutem (imiesłów ze zdania podrzędnego nie może doczekać się podmiotu w zdaniu nadrzędnym): „W ten sposób gramatyka anakolutu o d gry w a przesłonięcie podmiotu, które opisuje" 87 . Nie da się ustalić, czy ów błąd jest błędem („utrata kontroli”) - czy jest „ironia poety”, czy stał się już „ironią o nim” 88 .

Lektura a tergo, czyli, parafrazując słowa poety, czytanie nie bez s-krzypnięcia wstecz ironii, pozwala dostrzec ironiczny charakter „nieciąłłości między dwoma kodami retorycznymi” (AC 357) opisywanych w innych miejscach książki. Teksty Rousseau, nieważne czy mówią o miłości (Nowa Heloiza), wierze (Wyznanie wiary), czy o prawie (Umowa społeczna), stanowią „systemy tekstowe, których autorytet referencjalny był zarówno potwierdzany, jak i podważany przez ich logikę figuralna”" (AC 294). Działanie takich systemów widoczne jest np. w Umowie społecznej, w której dwuznaczne pojęcie własności, prywatnej i publicznej, wyznacza „Podwójna relacja jednostki wobec państwa” (AC 315) i strukturyzowane zostaje ono jak figuralny tekst: „ten sam pojedynczy byt (poszczególny kawałek ziemi) można rozważać jako referenta dwóch całkowicie rozbieżnych tekstów [...]” (AC 314).

Centralnym problemem jest ustanowienie przejścia między porządkami prywatnym i publicznym, ponieważ żadna metaforyczna totalizacja nie wydaje się tutaj możliwa - dobro ogółu nie musi być równoznaczne $z$ dobrem poszczególnych jednostek, w dodatku zbiorowość nie może wypowiedzieć swoich praw bez pośrednictwa prawodawców. Status prawodawcy, mediującego między państwem a wola jednostek, stanowi największą niejasność Umowy społecznej, prowadzącą, jak zauważył Czesław Porębski, do dwóch przeciwstawnych interpretacji tekstu - jako projektu utopii lub tyranii ${ }^{89}$. De Mana interesuje retoryczny, nie moralny wymiar alternatywy. Instancja zewnętrzna, prawodawca, jest „boskim autorytetem”, który spaja gramatykę państwa $\mathrm{z}$ retoryką jednostek $\mathrm{w}$ „systemie teologicznym zorientowanym na zbieżność figury i znaczenia” (AC 326). Autorytet zbudowany został na oszustwie retorycznym, metalepsis, w którym skutek (czyli stanowione prawa) należy przedstawić jako przyczynę (coś przyświecającego prawodawcy, a pochodzącego $z$ woli jednostek). De Man zauważa wreszcie, że „Rousseau nie identyfikuje się z żadnym z wielkich prawodawców [...]” i „wypiera się jakiejkolwiek formy boskiej inspiracji [...]” - sprzeciwia się więc tyranii, choć jednocześnie „nigdy nie ustaje w obronie konieczności prawodawstwa [...]" (AC 327). Broni zatem obietnicy, której spełnienie, jak stwierdza, pozostaje nierealne, „Umowa społeczna [...] jest faktycz-

89 Pierwsza interpretacja kładzie nacisk na suwerenność jednostki (obecność prawodawców byłaby wyborem typu second best, złem koniecznym wynikającym z niemożliwości osiagnięcia formy idealnej, w której wola jednostek przekładałaby się wprost na stanowione prawo), a druga widzi w idei prawodawców faktyczną dekretację ograniczenia wolności, całkowitego podporządkowania jednostki społeczeństwu. Zob. Cz. P o r ę b s k i, Umowa społeczna według Jana Jakuba Rousseau. W: Umowa społeczna. Renesans idei. Kraków 1999, s. 102-112. 
nie strukturowana jak aporia: uporczywie robi to, co ukazała jako niepodobieństwo do zrobienia" (AC 327).

Narracja Rousseau, ukazująca nieosiagalność dosięgnięcia przedmiotu, którego obraz stanowi, to alegoria, wciąż jednak „obiecująca niemało”, chociaż „utraciła [ona] prawo do obiecywania czegokolwiek" (AC 328). Rousseau jako autor Umowy społecznej sam zajmuje role prawodawcy (podstawia własne ,ja” w miejsce boskiego), co jest widoczne zwłaszcza w momentach nazwanych przez de Mana „sentymentalnymi i demagogicznymi”, w których pisarz wysila się, by przekonać o możliwości pogodzenia wolności jednostki $z$ umową społeczną. Odpowiada za to „język, nad którym Rousseau nie ma żadnej kontroli” (AC 329) - Rousseau traci kontrolę dokładnie w tym samym miejscu, w jakim traci ją Wordsworth w Esejach o epitafiach, gdy język zwraca się przeciwko autorowi i wypowiada te treści, którym zaprzecza. Tak jak Wordsworth krytykuje Pope’a za pomocą krytykowanego języka antytezy, tak Rousseau obnaża niemożliwość spełnienia obietnicy, którą jednak składa. Moment utraty kontroli to ironia, „permanentna parabaza alegorii (alegorii figury)" (AC 357), czyli niweczenie spójności tekstu, który w Obietnicach - analogicznie jak w Pojęciu ironii - uwalnia się od kontroli czytelnika-podmiotu, stając się własnością języka: „Błąd nie leży po stronie czytelnika; sam język odłącza poznanie od aktu” (AC 329).

Podobne aporie de Man odnajduje w odczytaniu wszystkich tekstów Rousseau - np. Wyznania wiary, gdzie „sądzenie stwarza tę samą możliwość referencji, która [...] unieważnia” (AC 279), czy Nowej Heloizy, gdzie „ciemność zapada wtedy, gdy oczywiste staje się, że język Julii zaczyna powtarzać pojęcia, które właśnie obnażyła ona jako błędy" (AC 259). Dynamika odczytań prowadzi niezmiennym rytmem od momentów jasności (wglądu, insight), kojarzonych $z$ alegoryczną dekonstrukcją iluzji przyległości metaforycznej, odpowiedzialnej za spójność tekstów, ku ciemności (ślepocie, blindness), w której poprzednią wiedzę zapomina się lub wypiera.

Widać to wyraźnie w Nowej Heloizie - „retrospektywna jasność” uzyskana zostaje w wyniku demistyfikacji alegorycznej (narracji odnoszącej się do poprzedniej narracji) wstępnego etapu miłości, opartego na symbolicznych „podobieństwach i zastapieniach ciała i duszy lub ja i innego" (AC 259). Ale język Julii naznaczony zostaje błędem, z którego dopiero co się wydźwigną - „Zwrot tematyczny” od erotycznego słownika panny do religijnego słownika mężatki nie wiąże się z porzuceniem zdekonstruowanej struktury (metaforyczną relację ja-kochanek zastępuje analogiczna relacja ja-Bóg). Dla badacza jest to bardzo poglądowa sytuacja, stwarzająca okazję do natychmiastowej ekstrapolacji, przejścia od lektury Nowej Heloizy do teorii czytania. De Man, jeśli tak można powiedzieć, utożsamia się z bohaterką powieści: „w chwili, gdy Julia uzyskuje maksymalny wgląd, utracona zostaje kontrola nad retoryka jej własnego dyskursu, zarówno przez nią sama, jak i przez nas" (AC 259). Ta wspólna utrata kontroli w Retoryce czasowości ujęta jest jako ruch w dialektyce „ja”, potknięcie się filozofa - następujące chwilę po tym, kiedy z uśmiechem otrzepuje on chiton po poprzednim upadku - w języku Pojęcia ironii zaś jako zdziczenie usamodzielnionego języka, wymykającego się temu, kto go używa. Oznacza to, po raz kolejny, że przed ironią nie chroni demitologizująca lektura, opisująca mechanizm jej działania. 
Myśl ta w czystej postaci pojawia się w eseju Roland Barthes and the Limits of Structuralism, rozpoczynającym się od apologii „euforycznego, z lekka maniakalnego” (RC 166) stylu Mitologii. Ale „pewność negatywna” (AC 28) czy „negatywna zasadność" (RC 176) osiaggana przez demitologizującą lekture jest - ubierając rzecz w terminy z artykułu Semiologia a retoryka, otwierającego Alegorie czytania - rodzajem „gramatyzacji retoryki”, która prześlepia swoją ekspozycję na wtórna „retoryzacje gramatyki”. Innymi słowy, Barthes nie wie, że wpisuje się w „szerszy schemat błędu" - demistyfikacja działa w Mitologiach w oparciu o demistyfikowane metafory (semiotyczne relacje: wnętrze-zewnętrze, znak-znaczenie). To właśnie „niemożliwość oczyszczenia własnego dyskursu z aberracyjnie referencjalnych implikacji” (RC 174) sprawia, że francuski filozof, podobnie jak powieściowa heroina, traci kontrolę nad tekstem, nawiedzanym przez „widmową figure” ironii.

W bardziej zawiłych okolicznościach nad swoim wywodem przestaje panować György Lukács. W Teorii powieści ironia zostaje wszakże ujawniona jako sygnał alienacji człowieka w świecie opuszczonym przez bogów, wyraża napięcie między idealnym a realnym w powieści, niezdolnej do odtworzenia organicznej totalności bijącej z greckich źródeł epiki. Rzecz jednak w tym, twierdzi de Man, że badacz w drugiej części książki zamaskowuje „strukturalne nieciagłości” (B 56) za pomocą pozytywnego pojęcia czasowości, przywracającego źródłowe kontinuum:

Wydaje się, że organicyzm, wyeliminowany przez Lukácsa z powieści, gdy uczynił z ironii jej przewodnią zasadę strukturalną, ponownie wchodzi w pole widzenia w przebraniu czasu. [B 58]

Owa maskarada potrzebna jest Lukácsowi, by ukonstytuować ciagłość (organiczność) własnego wywodu, przedstawiającego historyczny rozwój powieści $z$ nadrzędnego, wszechwiedzącego punktu widzenia: „To sama powieść opowiada nam historię swojego rozwoju" (B 53). A zatem ironia, która na poziomie tematu zostaje u Lukácsa zneutralizowana przez czas, nawiedza tekst na poziomie konstrukcji wywodu, ciążącego ku utopii ciagłości, zanegowanej wcześniej przez „donkiszotowskie napięcie" (B 55) w obrębie formy powieściowej.

$\mathrm{O}$ tym ponawianym „schemacie błędu” mówi wiele znanych fragmentów z Alegorii czytania. Np. w rozdziale o Nowej Heloizie:

Dekonstrukcje tekstów figuralnych wytwarzają klarowne narracje, które z kolei, by tak rzec, w swej teksturze powodują ciemność groźniejszą niż błąd, który oddaliły. [AC 259]

Na wzorzec wszelkich tekstów składa się figura (lub system figur) i jej dekonstrukcja. Ponieważ jednak model taki nie może być domknięty przez ostateczne odczytanie, tworzy on z kolei uzupełniającą nakładkę 〈superposition〉 figuralną, która opowiada o nieczytelności pierwszej narracji. [AC 246]

- oraz w tekście o Emilu:

Odczytania dekonstrukcyjne mogą wskazać bezpodstawne identyfikacje dokonane poprzez zamianę, ale nie są w stanie zapobiec ich ponownemu wystąpieniu nawet w ich własnym dyskursie $\mathrm{i}$, by tak rzec, odkrzyżować dokonane już zmiany. Ich gest powtarza jedynie retoryczne zniekształcenie, które przede wszystkim wywołało ten błąd. [AC 288]

Żaden dzień nie chroni przed nawrotem nocy, choć w przytoczonych fragmentach nie wini się za to wprost ironii. Jakkolwiek nie mówi się w nich o zerwaniu iluzji czy zawieszeniu narracji, to same te wypowiedzi stanowia parabazy, w których czytanie Rousseau zostaje przerwane i zastąpione przez metaopis podważający to 
czytanie. W tym uniwersalnym wzorcu tekstualności dekonstrukcja figury jest inherentna - aporia jezzyka performatywnego i konstatywnego zmusza każdą narrację (czyli jakikolwiek „system figur”, zarówno listy Julii, jak i teorię Fichtego) do zmierzenia się ze swoim cieniem, czyli z alegorią opowiadająca o „nieczytelności pierwszej narracji”. Dekonstrukcyjne odczytanie nie wyłamuje się z klinczu, ale generuje następna „klarowną narrację”, która nie „domyka” ani nie „odkrzyżowuje” lektury, lecz jedynie demistyfikująco ją parafrazuje za pomoca „nakładki figuralnej”, powtarzającej „retoryczne zniekształcenie” na innym poziomie alegoryzacji.

Łatwo zauważyć miejsce, w którym opisany schemat interferuje $z$ koncepcją ironii wyłożoną w Retoryce czasowości oraz w Pojęciu ironii: „Sam zawsze jesteś przez siebie opisany". Zofia Mitosek stwierdza:

Jeżeli jednym $\mathrm{z}$ sygnałów ironiczności wypowiedzi jest zawarta w niej informacja o warunkach i ograniczeniach jej powstania, to ironia stała się ostatnio losem teorii literatury ${ }^{90}$.

Słowo „ostatnio” trzeba rozciagnąc tak, by objęło swoim zasięgiem jenajczyków - dekonstrukcja de Mana stanowi parafrazę romantycznej poezji transcendentalnej, która korzysta ze swojej dialektycznej nośności (schweben, Reflexion itd.), by - opisując jakieś przedmioty (,nie-ja”) - badać jednocześnie warunki swojego istnienia (,ja”). Czytaniu u de Mana, tak jak pisaniu u Schlegla, towarzyszą pomruki alegorii i błyskawice ironii, za których sprawą okazują się one „nieskończonym procesem bez syntezy". Odkrycie symetrycznego wzorca figuralnego w powieści Rousseau (i w innych analizowanych utworach) oraz we własnym wywodzie nie pozwala na łatwe rozdzielenie literatury, krytyki i filozofii „wzdłuż osi epistemologicznej, która odróżnia gramatykę od retoryki” (AC 29), co znowuż jest ironicznym negatywem synkretyzmu romantycznego, Schleglowskiego postulatu „zbliżenia poezji do filozofii i retoryki”.

W kontekście tych rozważań istotne wydaje się pytanie Lipszyca: „Czy teoria de Mana jest [...] powtórzeniem, przypomnieniem, czy dekonstrukcją koncepcji Schlegla"91? Badacz, nie roztrząsając kwestii, skłania się ku ostatniemu rozwiązaniu. Wydaje się jednak możliwe, że zawiera ono w sobie dwie poprzednie - lektura dekonstrukcyjna, ujmowana przez de Mana konsekwentnie jako alegoria nieczytelności, jest właśnie powtórzeniem, „znakiem powtarzającym poprzedzający znak” (RC 392), „uzupełniającą nakładką [...] figuralną” (AC 246), którą da się również interpretować w kluczu pamięci jako dialektykę „alegorycznej Mnemosyne” i ,ironicznej Lete" ${ }^{2}$.

Jednym $\mathrm{z}$ dziwnych nawyków de Mana, który podobno bardzo bawił jego żonę, było przeciagłe, narcystyczne wpatrywanie się w swoje lustrzane odbicie ${ }^{93}$. Myśl o ironii jako o grze lustrzanych refleksów, jako o zawrocie głowy prowadzacym do kresu świadomości, jako o negatywnej sile języka niszczącej każdą opowieść po-

Z. Mito sek, Co z ta ironią? Gdańsk 2013, s. 30 .

Lip szy c, op. cit., s. 143.

Do problematyki pamięci de Man nawiązuje wprost w interpretacji Estetyki G. W. F. H e gla, która postrzega jako „dwulicowy tekst” (I 153), tający wpływ „alegorycznej” pamięci (Gedächtnis) na działanie systemu promującego pamięć „symboliczną” (Erinnerung) (I 151) - zob. I 151-157.

Zob. B aris h, op. cit., s. 398. 
wraca obsesyjnie w twórczości dekonstrukcjonisty, choć często w zawoalowany sposób. W poszukiwaniu tej latentnej ironii można sięgnąć do początków pisarskiej ścieżki de Mana. W młodzieńczych, powstałych jeszcze w Belgii szkicach o symbolizmie i kubizmie (o pracach Paula Valery'ego i Jacques'a Villona), związanych z zatrudnieniami w oficynie „Hermes”, wydającej albumy o sztuce, dostrzegamy prefigurację zainteresowań ironią jako modelem dekompozycji tekstualnej i nieskończonej rekurencji. Widać to w przestrzennych metaforach, które przyciagają uwagę piszącego „siatką równoległych linii oddalających się w odległa przestrzeń”, „tworzących świat z nieskończoną ilością możliwości, ograniczony płaszczyzną płótna czy tablicy" (P 41).

$Z$ drugiej strony, dobrą ilustracją panironiczności pisarstwa de Mana jest jeden z jego późniejszych tekstów, Opór wobec teorii, w którym przedstawia on subwersywną rolę retoryki w ramach struktury trivium, przekreślająca jego „dążenie [...] do bycia epistemologicznie stabilną konstrukcją" $(\mathrm{O} 100)^{94}$. Retoryka rozszczelnia system, a system broni się poprzez jej wykluczenie bądź próby ujarzmienia, co prowadzi do wniosku, że „Opór wobec teorii jest oporem wobec retorycznego, czyli tropologicznego wymiaru języka [...]” (O 100).

Przykładem anarchii nierozstrzygalności wprowadzanej do systemu przez retorykę jest dla de Mana późny poemat Johna Keatsa Upadek Hyperiona - sen (The Fall of Hyperion - A Dream). Badacz odkrywa intertekstualną dwuznaczność tytułowego upadku, który odnosić się może do Hyperiona, ustępującego tytana, ale pośrednio i do Hyperiona, czyli poprzedniej, nieukończonej wersji utworu. Jego odczytanie jako historii upadku (tzn. fiaska artystycznego) wcześniejszego tekstu zostaje wzmocnione przez postać artysty-Apolla, który ma zająć miejsce tytana. Jako że poeta w utworze jest zwykle figurą autotematyczną, obnażającą fikcjonalność świata (J. Słowacki zasugerował to w Beniowskim w obrazie „antropofaga”, który zjadł "poetę, może z poematem w głowie”), de Man dostrzega w bóstwie rysy samego Keatsa. Wyjaśnia tym samym, dlaczego pozornie zwycięski Apollo jest samotny i zagubiony - Upadek Hyperiona - sen, poemat przez Keatsa również nie dokończony, opisuje kolejną fazę tytułowego upadku. Podążając za tym odczytaniem, można spekulować, że doczekalibyśmy się następnej niedokończonej części, która byłaby zatytułowana: The Fall of The Fall of Hyperion ${ }^{95}$, gdyby nie przedwczesna śmierć samego autora. Dekonstrukcjonista wyostrza aporię, wskazując na obrotową dwuznaczność tytułu (,of' w funkcji dopełniacza lub przydawki), która utrudnia podjęcie decyzji, czy chodzi najpierw o upadek („upadek Hyperiona”), czy o Hyperiona („Hyperion upadający”), a więc o coś, co raz się przydarzyło, czy raczej o coś, co przydarza się nieustannie Hyperionowi, Apollinowi, Keatsowi, w domyśle zaś wszystkim poetom i poematom.

Historia zmierzchu tytanów jawi się de Manowi jako epicka autodiagnoza,

Dwa akapity poświęcone Oporowi wobec teorii są zmodyfikowaną wersją fragmentu artykułu Nieromantyczne ironie romantyczne, który ukazał się wcześniej w zbiorze Romantyzm $w$ lustrze postmodernizmu (i odwrotnie) (Red. W. Hamerski, M. Kuziak, S. Rzepczyński. Warszawa 2014, s. 193-195).

95 Podaję ten fikcyjny niby-tytuł w języku angielskim, żeby uchwycić niewyrażalną w języku polskim obrotowość słowa „of' oraz możliwą pełną iteratywność (ironiczną!) upadków. 
mówiąca o niemożliwości doskonałego i ostatecznego zastępstwa, czyli pełnej i skończonej reprezentacji. Badacz odnajduje w tekście figurę swego własnego odczytania - analogiczną do tych z Lat nauki Wilhelma Meistra i drugiej ksiegi Don Quichotte’a, a więc kluczowych przykładów Schlegla - dokonując ekspozycji techniki „permanentnej parabazy”. Jak widać, gdzie drwa rąbią, wióry lecą: odpryskiem, nienazwanym skutkiem ubocznym artykułu, który mówi o tym, że gramatyka nie chroni przed alternacją retoryczną, jest prezentacja poematu Keatsa jako arcydzieła ironii romantycznej! Można zatem powiedzieć, że tym, co w Oporze wobec teorii stanowi zagrożenie dla systemu (teorii), jest w takim samym stopniu retoryka, co ironia, która wszak z domostwa tej pierwszej została przez romantyków wyprowadzona. Opis działania retoryki jako „pseudodialektyki własnego przekreślenia" (nie da się pomyśleć trivium bez dialektyki i retoryki) jest kryptonimowanym opisem ironii negującej świat, którego jest częścią. „Nic nie może przezwyciężyć oporu wobec teorii, gdyż sama teoria jest owym oporem" (O 105) - pokrętna koda dekonstrukcjonisty wchodzi w konflikt ze zdrowym rozsądkiem, ale pozostaje w zgodzie z refleksją Schlegla (o którym w artykule w ogóle się nie wspomina), a powinno się nawet powiedzieć, że rekontekstualizuje - co zauważył Kevin Newmark - jego słynny aforyzm o potrzebie posiadania systemu i braku systemu. To paradoksalne połączenie zawiera dwa najistotniejsze składniki, które Schlegel ,już to miesza, już to stapia” w nadziei wydestylowania poezji/powieści sankcjonującej syntezę i tym samym ruchem pióra przekreślającej ją. Newmark podsumowuje: „Teoria literatury jest dla de Mana, tak samo jak dla Schlegla, literatura jako teorią" 96 .

\section{Triumf życia}

Ponieważ ironia romantyczna opiera się na subtelnej oscylacji między wolnością a koniecznością, potrzebą a niemożliwością rozumienia, istnieje tendencja, potwierdzona w recepcji, by redukować ją do jednego $z$ dwóch ujęć: pozytywnego (dawałaby wtedy szanse pojednania, np. w sztuce) lub negatywnego (ironia udaremniałaby jakąkolwiek syntezę). O „dwóch obliczach” ironii pisała m.in. Bielik-Robson, przeciwstawiając Schlegla (i jego kontynuatora, de Mana), który wprowadza dialektyke ,ja” w „stan dynamicznego paraliżu”, „zacierając [...] wymiar progresywny”97, Kierkegaardowi (i jego następcy, Bloomowi) - dla niego ironia jest „trywialnym odruchem obronnym" ${ }^{98}$, zaledwie początkiem ruchu podmiotowości. Filozofka konsekwentnie posługuje się przemawiającymi do wyobraźni opozycjami, w których de Man, co zrozumiałe, zajmuje miejsce „śmiercionośnego Apolla”99 ogłaszającego pod osłona „, nocy dekonstrukcji” 100 nieunikniony „triumf Tanatosa” ${ }^{101}$. Zapaśniczy uścisk, w jakim pozostaja heroldowie śmierci i piewcy życia, przypomina Bloomow-

\footnotetext{
New mark, op. cit., s. 21.

Bielik-Robson, op. cit., s. 210.

Ibidem, s. 246.

A. Bi elik-Robs o n, „Na pustyni”. Kryptoteologie późnej nowoczesności. Kraków 2008.

Bielik-Robson, Duch powierzchni.

Bielik-Robs on, „Na pustyni”.
} 
ski agon (wpisuje się on, jak zauważa Michał Paweł Markowski, w „manichejski obraz świata" samej filozofki ${ }^{102}$ ), będący wszakże specjalnością tych drugich, co na wstępie daje przewagę stronie, $z$ którą Bielik-Robson sympatyzuje.

Opozycje porządkują, ale również zawłaszczają - niejednorodna i wieloznaczna twórczość Schlegla na pewno pozostawia margines na interpretację, akcentującą pozytywna energię jego ironii. Warto przypomnieć reakcję autora Fragmentów (w jednym z pierwszych aforyzmów w „Athenaeum”) na zaszczepienie negatywności w „mądrości światowej”: „Czy wprowadzenie do filozofii pojęcia pozytywności nie byłoby także czymś pożytecznym?" ${ }^{103}$ Progresywność pozostaje w horyzoncie nurtów recepcji Schlegla, ukazujących „działanie scalające i ocalające ironii” ${ }^{104}$, która „nie pozwala na zastygnięcie ruchu myśli” i daży do „poszerzania sensu” ${ }^{105}$, lub przynajmniej próbujacych „położyć nacisk na pozytywność doświadczenia negatywnego” 106 , polegająca na zdolności „zaprzeczania fałszywym syntezom”, odkrywania „negatywnej utopii” jako stałej wiedzy o nierealności utopii ${ }^{107}$.

Możliwość przywrócenia Schleglowi „progresywności” lub chociaż zrewaloryzowania „dynamicznego paraliżu”, otwiera furtkę do poszukiwań momentów pozytywnych na via negativa, która podażał de Man - „inkarnacje poetyckie” 108 autora powieści Lucinde. Trudno je znaleźć w ramach mimetycznej lektury pism dekonstrukcjonisty, jaka jest Duch powierzchni. Bielik-Robson prezentuje sylwetkę badacza jako nieprzejednanego stronnika „paraliżującej skepsis”, piętnującego „skepsis połowiczną", cechującą np. Friedricha Nietzschego, który obnaża iluzję podmiotowości, by samemu zająć miejsce „silnej podmiotowości” 109 .

Pojawia się jednak wątpliwość: czy de Man, wywyższający się nad Nietzschego jako bardziej radykalny sceptyk, sam nie zamienia się w silny podmiot, który wcześniej zdekonstruował? Duch powierzchni nie poddaje tego tematu refleksji, ale, co ciekawe, w kolejnej książce, „Na pustyni”. Kryptoteologie późnej nowoczesności, autorka powraca do przykładu $z$ Nietzschem - porzucając mimetyczny styl odbioru, odkrywa w de Manie samoświadomego narratora, który wykazuje „przeczulona troskę o to, by nie dać się złapać na ustanowieniu uprzywilejowanego punktu obserwacji [...]" ${ }^{110}$. Być może, retusz w portrecie de Mana, nie wpływający w istotny sposób na jego kiepskie notowania, dokonał się pod wpływem polemiki z Markowskim, który zarzucił filozofce, że traktuje literaturę „całkowicie użytkowo”, a czytając romantyków przeciwko nim samym (wielu definicji ,ja” romantycznego „nie należy brać dosłownie, lecz w istocie dokładnie odwrotnie [...]" ${ }^{111}$ ), postępuje po-

M. P. Mark ow s ki, Przeciwko gnostykom. „Literatura na Świecie” 2005, nr 11/12, s. 393.

Schlegel, Fragmenty, s. 41.

Szt u r c, Ironia romantyczna, s. 144.

M. P. Mar k ow s ki, Poiesis. Friedrich Schlegel i egzystencja romantyczna. Wstęp w: S c hle gel, Fragmenty, s. LXXI.

J. Corby, Emphasising the Positive: The Critical Role of Schlegel's Aesthetics. „The European Legacy. Toward New Paradigms" 2010, nr 6, s. 752.

Finlay, op. cit., s. 169.

Bielik - Robs on, Duch powierzchni, s. 205.

Ibidem, s. 365, 377.

Bielik-Robs o n, „Na pustyni”, s. 194.

Bielik-Robs on, Duch powierzchni, s. 13. 
dobnie jak krytykowany przez nią de Man ${ }^{112}$. Przeciwnie za to obchodzi się z samym dekonstrukcjonistą, przyjmując jego „śmiercionośne” i „rygorystyczne” tezy zupełnie dosłownie, bez wrażliwości literackiej na uporczywą autoironię, zjawiającą się nieuchronnie, gdy autor Alegorii czytania stwierdza, zazwyczaj stanowczo, że nie ma szczelnych narracji, wolnych od ryzyka samozagłady. Dla Bielik-Robson autorefleksja jest po prostu sprytnym sposobem odzyskania władzy poprzez jej pozorne zrzeczenie się, narzędziem tanatycznej kryptoteologii. Filozofka opisuje ją bardzo dowcipnie - prawda powraca „potajemnie i cichcem” do wywodu „tanatycznego mistyka i uniżonego sługi języka", poddającego się rygorowi ascezy w celu odzyskania „niewzruszonej stabilności podmiotu, wiedzącego, że umieszcza się na zewnątrz szalejącej natury, której dzikość nie może go dotknaç" 113 .

Tymczasem de Man wielokrotnie sugeruje, iż skepsis nigdy nie jest dość wyrafinowana i nieustannie zagraża jej błąd podmiotowości. Wiedza ta nie zjawia się „potajemnie i cichcem”, lecz jako „roszczenia metodologiczne tym bardziej nabożne, że odrzucają one jakiekolwiek nabożeństwo" (S 270). Interpretacyjna monumentalizacja nie stanowi według de Mana posunięcia, „którego ktoś mógłby rzekomo unikać” (S 269), a utrata „kontroli nad retoryką [...] własnego dyskursu, zarówno przez nią samą [tj. Julię], jak i przez nas" (AC 259), przychodzi w momencie największej przenikliwości. W innym miejscu badacz podkreśla, iż niepodobieństwo uzyskania spójnej narracji (ani teorii tej narracji) „Nie oznacza [...], że nie powinniśmy dalej nad tym pracować, ponieważ tylko to możemy robić [...]" (I 274). Potraktowanie „my” w przytoczonych wypowiedziach jedynie jako tropu „wy” byłoby uproszczeniem, nie liczącym się z konsekwencjami autoironicznej teatralizacji dzieł dekonstrukcjonisty, wyraźnie inspirowanych przez romantyków. Permanentne od-twarzanie żeruje na swoim dialektycznym przeciwieństwie, czyli na nadawaniu oblicza, a gest przekreślający ,ja” stanowi inskrypcję tego ,ja”.

Owa uwewnętrzniona strategia wywodu pokazuje, że de Man nigdy całkowicie nie odrzucił myślenia o ironii jako dialektyce podmiotu. „Czy podmiotowość nie może być definiowana jako błąd gramatyczny?” - pyta Johnson w cytowanym wcześniej artykule o anakolutach w Alegoriach czytania, po czym odpowiada: „tekst de Mana wpisuje ślady podmiotowości w miejsce opuszczone przez podmiot gramatyczny" 114 . Podmiotowość rozumiana jako błąd, anakolut, czyli potknięcie ironiczne, rozwijać się musi w środowisku narracji (alegorii) - po prostu trzeba zacząć iść, aby móc potknąc się i upaść. Jak zauważa Claire Colebrook, opowiadanie (a przecież „tylko to możemy robić”) stanowi podstawową „podmiotową aktywność, nad którą jednak nigdy nie ma pełnej kontroli, co de Man wyraża poprzez typowo ironiczne „upieranie się przy niemożliwości oraz nieuniknioności podmiotu" 115 .

Przypuszczenie, że dekonstrukcjonista postanowił „wyzuć język z wszelkich pozorów życia [...]" ${ }^{116}$, znajduje wprawdzie uzasadnienie w metaforach języka jako maszyny: „Tekst jako ciało [...] przemieszczany jest przez tekst jako maszynę [...]”

Zob. M. P. Mar kow s ki, Spektakularna spekulacja. „Literatura na Świecie” 2005, nr 9/10, s. 363.

Bielik-Robs o n, „Na pustyni”, s. 199, 196-197.

J o h n s o n, op. cit., s. 80.

115 Colebrook, op. cit., s. 110.

116 Bielik-Robson, „Na pustyni”, s. 183. 
(AC 354), język ironii to „maszyneria, maszyneria tekstowa, nieuchwytna determinacja i całkowita arbitralność” (I 277), itd. Z drugiej strony, język w języku de Mana stanowi byt migotliwy, badacz portretuje go również odmiennie, jako żywy, nieobliczalny organizm: „Ironia pojawia się wtedy, kiedy język zaczyna mówić rzeczy, o których mówienie go nie podejrzewałeś [...]” (D 248), a „Słowa mają taki sposób mówienia, że wypowiadają nie to, czego byśmy sobie życzyli” (I 277), itd. Oczywiście, nie możemy naiwnie przyjąć, iż nadając głos i oblicze językowi, odzyskujemy nad nim panowanie - antropomorfizm to tylko „złudne wskrzeszenie naturalnego oddechu języka” (AT 128), które nie uwalnia go od niezrozumiałości.

A zatem to nie figury życia, ale samo życie figur ocala element podmiotowy i twórczy w pisarstwie de Mana, na przekór jego kokieteryjnemu zapewnieniu (które samo w sobie stanowi mały triumf podmiotu), iż poprawne odczytania sa „nudne, monotonne, przewidywalne i nieprzyjemne" (O 104). Figury zbaczają z kursu, zaciemniaja, mistyfikują, lecz jednak żyją. Do takiego wniosku dochodzi Paweł Stachura, który do lektury tekstów de Mana wykorzystuje teorię automatów. Według Stachury interpretacje dekonstrukcjonisty dążą do tego, „by tekst nie poddawał się formalnemu zamknięciu”, jego myślowa wędrówka okazuje się dość niespodziewanie nieustanną ucieczką przed maszynami („można przypuszczać, że jako humanista de Man bał się maszyn"). Podczas ucieczki badacz korzysta z pomocy innych maszyn, takich jak ironia, czyli „automat nieskończony”, „formalizm, którego celem jest zniweczenie innego formalizmu [...]"117 (chociaż wydaje się, iż sprowadzenie ironii do funkcji generatora dwóch przeciwnych stanów niewiele mówi o jej subtelnościach).

Ironia niszczy spójność systemu tropologicznego, ale nie może zlikwidować samych tropów. Co prawda, „retoryka wypierana jest przez gramatykę, która ją dekonstruuje”, lecz trudno tym się zadowolić, skoro „narrator, który mówi nam o niemożliwości metafory, sam jest jakąś metaforą [...]" (AC 31). Jeżeli każda dekonstrukcja metafory stanowi metaforę, formalne okiełznanie tropu staje się niemożliwością - w tym momencie automat, zauważa Stachura, nie mogąc zakwestionować samego siebie i wypowiedzieć niektórych zdań samozwrotnych, zawiesza się. To źle dla potencjalnej retoryki ironii, ale dobrze dla życia tekstu: „Retoryczne zwierzę dlatego jest wolne i dzikie, że nie daje żadnych wskazówek, która z [...] interpretacji jest prawdziwa" ${ }^{118}$. Język w tekstach de Mana błądzi, bywa maszyna, zwierzęciem, człowiekiem, ale zawsze napędzają go tropy, które wymykają się spod kontroli, powodując „szaleństwo słów” (S 270), „głupotę i obłęd”, przydarzające się jednak ludziom, nie maszynom.

Gdyby odnieść do strategii lekturowej de Mana typologię sposobów czytania, wyinterpretowana przez niego $\mathrm{z}$ opowiadania $O$ teatrze marionetek Heinricha von Kleista, można by powiedzieć, że nie jest on niedźwiedziem-fechmistrzem, o czym na pewno próbowałaby przekonywać Bielik-Robson, czyli „superczytelnikiem” parującym wszystkie sztychy autora, bezbłędnie przy tym odróżniającym pchnięcia

P. S ta c h u ra, Automaty i tygrysy. Dzikość $i$ skamieniałość figur retorycznych według de Mana. W zb.: Siła komentarza. Romantyzmy literaturoznawców. Red. J. B o r o w c zy k, W. H a m e r s k i, P. Śniedzi ewski. Poznań 2011, s. 99, 104. 
zadawane serio od pozorowanych. Dekonstrukcjonista, zachwycający się wyzutą ze świadomości „maszyneria języka”, przypomina raczej pana C., który delektuje się mechanicznym tańcem marionetek, „oczyszczonym $z$ patosu samoświadomości” (RR 286). Ale sam pan C. (ani de Man) nie jest marionetką, tylko tancerzem, który:

musi stale przerywać swe poruszenia krótkimi okresami spoczynku nie należącymi do samego tańca. Są one jak parabazy ironicznej świadomości, która musi odzyskać energię po każdej porażce przez wpisanie tej porażki w postępujący proces dialektyki [...]. [RR 287] ${ }^{119}$

Ostateczny los języka, poety i jego czytelników waży się w postapokaliptycznym Shelleyu odkształconym, z figury doszczętnie odartym. Trudno sparafrazować lub oddać ducha tego późnego, drapieżnego eseju o niedokończonym utworze Shelleya Triumf życia. W poemacie „odpowiedzią na pytanie jest kolejne pytanie”, a „dialektyczna progresja czy regresja" (S 247) okazuje się mrzonką, maskującą prawdę o „szaleństwie słów”. De Man skupia uwagę na wizji, jakiej doświadcza Rousseau, który sam jest wizja podmiotu wiersza. „Kształt postaci całej ze światła” w odczytaniu badacza zamienia się w „figurę figuralności wszelkiego oznaczania” (S 264). Stanowi więc onirycznie zapośredniczoną alegorię czytania - podmiot-tekst odnajduje sam siebie w tym widzeniu niczym Henryk z powieści Novalisa, który w „cudowny sposób” wchodzi w kontakt ze swoją postacią, „dość rozpoznawalną pośród innych figur" zapełniających księgę pustelnika. Henryk, tak jak Rousseau, Shelley i de Man, „nie rozumiał z niej ani jednej zgłoski”, dlatego że „kształt” i „figura” pozostaja kształtem i figura, ich „samozanikanie [...] zatrzymuje proces rozumienia” (S 247). W poemacie Shelleya można to dostrzec w porównaniu mózgu do piaszczystej plaży zalewanej morską falą. Na piasku malują się „więcej niż w połowie starte” ślady łani, która pierzchła przed „srogim wilkiem”, ten jednak ,już pozostawia swój widoczny znak na brzegu" (S 247). Zagadkowy obraz mówi de Manowi coś o Rousseau - bohaterze utworu (to figury jego natury: delikatnej i gwałtownej), ale i o naturze samej figury. Rytmiczna fala, niczym staccato ironii, wymazuje tropy i ślady, chociaż wilk i łania wciąż na nowo odciskają historię nieustającego polowania. „Proces ten nie ma końca [...]” (S 268), ponieważ przynależy do rodzaju, który „wiecznie może się tylko stawać, a nigdy się nie spełnić” ${ }^{120}$, do myślenia, które znajduje się zawsze in medias res, tak jak romantyczna ironia oraz dekonstrukcja.

Gasché słusznie postuluje, by lekcję czytania, jakiej udziela de Man w Shelleyu odkształconym, przećwiczyć na jego własnym odczytaniu ${ }^{121}$. Ćwiczmy zatem: de Man jako czytelnik jest wilkiem dopadającym łanię - odkształca, odziera z figury, pozbawia twarzy, rozszarpuje włókna narracji. Ale jest również łanią, którą ten wilk przydusza pazurami do piasku, by w nieoczekiwanym momencie rozerwać ciało-tekst. Taką właśnie trajektorią podąża de Manowska lektura, pozostawiając zawsze „śladową resztkę”, mniej niż w połowie starty trop, błąd, który można nazwać życiem. 


\section{Abstract \\ WOJCIECH HAMERSKI Adam Mickiewicz University, Poznań \\ ROMANTIC IRONY IN PAUL DE MAN'S WRITING}

Romantic irony is subject of reflection mainly in Paul de Man's two pieces, namely The Rhetoric of Temporality and The Concept of Irony. The aim of the article is to indicate that many structures of thinking derived from the key aesthetic structure of Early German Romanticism also act in the deconstructionist's other writings. In this mode the romantic irony becomes a hero - often unnamed, but important - of de Man's most crucial arguments presenting his aporia-centered concept of language and literature. The article also takes up the issue of de Man writings' reception; it seems that incomprehension or open reluctance they often evoke stem from their too-literal reading. De Man, by contrast, though often in a veiled way, demands from his audience a non-literal reading (in line with the assumed non-obviousness of the borderline between literature and criticism), while irony for de Man is not only a subject of research, but a writing method itself strongly inspired by the creativity of the Romantics. 